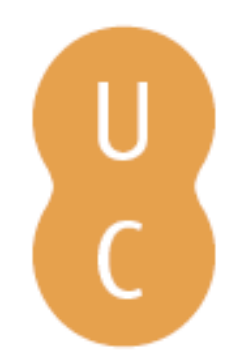

\title{
pompalina
}

\section{O urbanismo da Mafalala: origem, evolução e caracterização}

Autor(es): $\quad$ Gonçalves, Nuno Simão

Publicado por: Imprensa da Universidade de Coimbra

URL

persistente: URI:http://hdl.handle.net/10316.2/39295

DOI: $\quad$ DOI:http://dx.doi.org/10.14195/978-989-26-1220-1_5

Accessed : $\quad$ 26-Apr-2023 02:28:44

A navegação consulta e descarregamento dos títulos inseridos nas Bibliotecas Digitais UC Digitalis, UC Pombalina e UC Impactum, pressupõem a aceitação plena e sem reservas dos Termos e Condições de Uso destas Bibliotecas Digitais, disponíveis em https://digitalis.uc.pt/pt-pt/termos.

Conforme exposto nos referidos Termos e Condições de Uso, o descarregamento de títulos de acesso restrito requer uma licença válida de autorização devendo o utilizador aceder ao(s) documento(s) a partir de um endereço de IP da instituição detentora da supramencionada licença.

Ao utilizador é apenas permitido o descarregamento para uso pessoal, pelo que o emprego do(s) título(s) descarregado(s) para outro fim, designadamente comercial, carece de autorização do respetivo autor ou editor da obra.

Na medida em que todas as obras da UC Digitalis se encontram protegidas pelo Código do Direito de Autor e Direitos Conexos e demais legislação aplicável, toda a cópia, parcial ou total, deste documento, nos casos em que é legalmente admitida, deverá conter ou fazer-se acompanhar por este aviso.

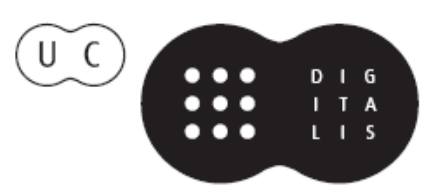


MARGARIDA CALAFATE RIBEIRO

WALTER ROSSA

[ORG.]

\section{MEMÓRIAS \\ E ESPAÇOS \\ DE UM LUGAR}

II

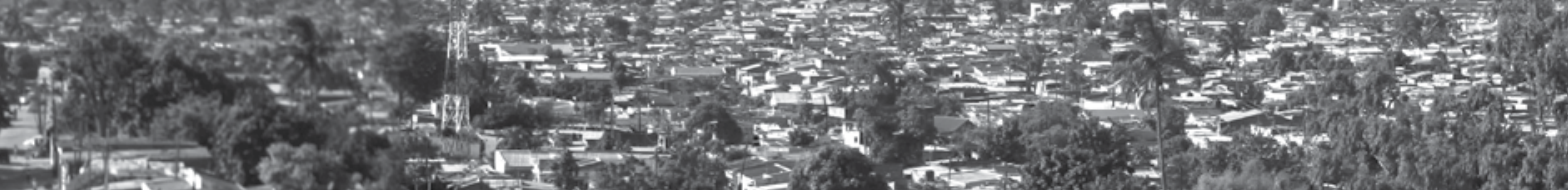

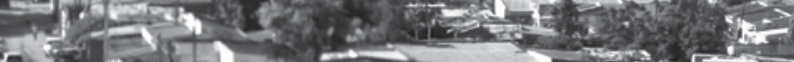

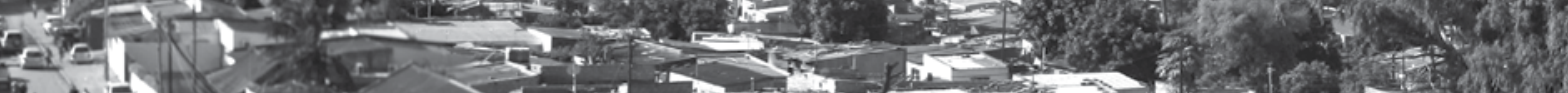

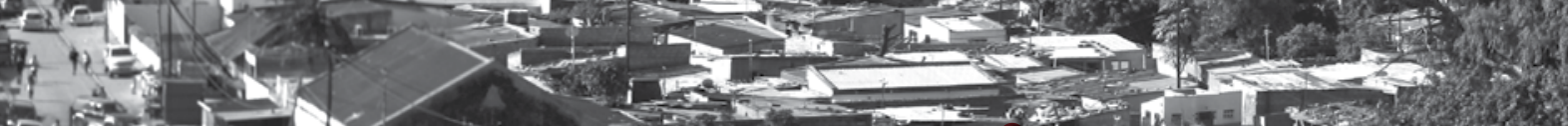

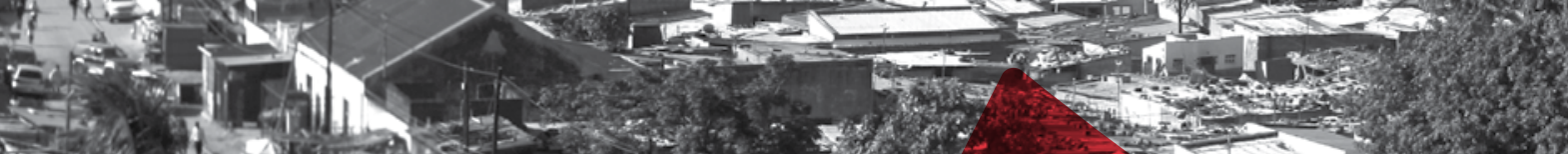
a.

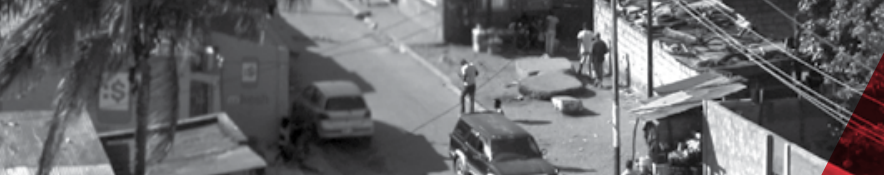

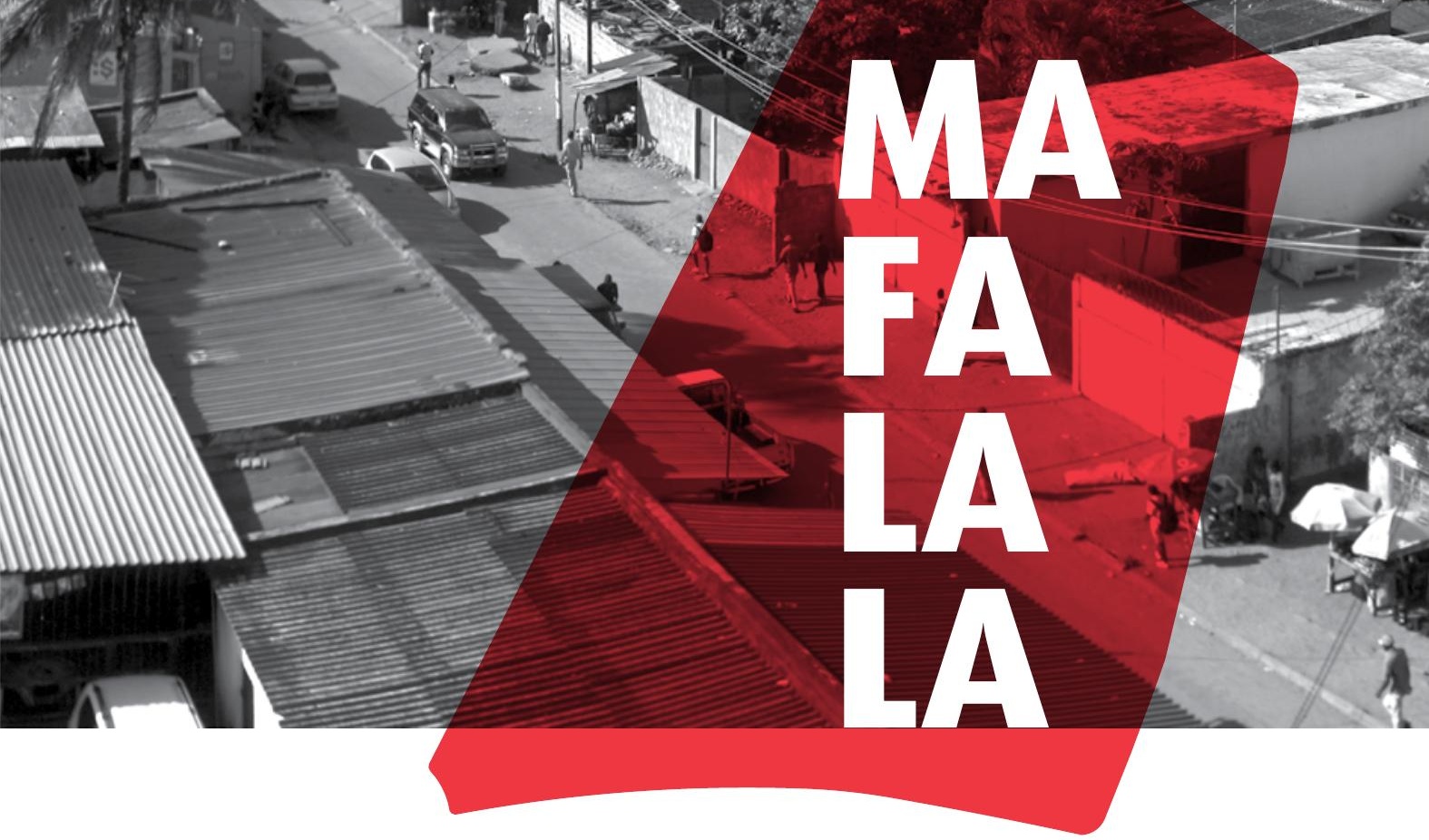




\title{
O URBANISMO DA MAFALALA:
}

ORIGEM,

\author{
EVOLUÇÃO \\ E CARACTERIZAÇÃO
}

Nuno Simão Gonçalves

\begin{abstract}
ste texto descreve a evolução urbana do Bairro da Mafalala. Apesar das semelhanças com outros bairros situados do lado exterior da circunvalação da cidade de Maputo, o Bairro da Mafalala tem características que o distinguem dos demais. Essas particularidades são mais evidentes no tecido social, onde a heterogeneidade das origens dos seus habitantes gerou uma urbanidade que se destaca na capital de Moçambique.
\end{abstract}

A historiografia urbana da cidade tem incidido sobre a zona projetada pelos e para os europeus, conhecida no tempo colonial, primeiro como cidade dos brancos (xilunguíne em ronga), depois como cidade de cimento. Em seu redor foi crescendo outra cidade, outrora denominada caniço ${ }^{1}$, onde a população autóctone e outros grupos desfavorecidos da hierarquia colonial, viveram segregados até à independência, em 1975. As origens da Mafalala são bem mais ancestrais e abrangentes que os limites impostos pelos europeus no final do século XIX. Também a riqueza sociocultural e urbanística do bairro extrapola as fronteiras demarcadas pelas quatro avenidas que definem o seu perímetro. 


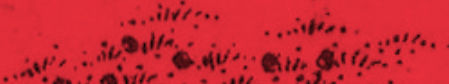

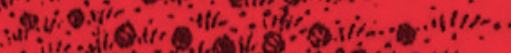
$\therefore$ ir

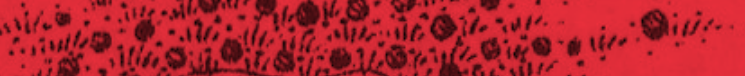

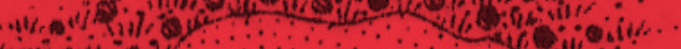

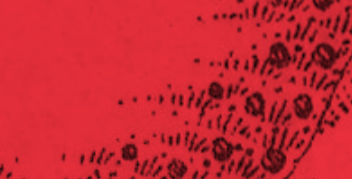

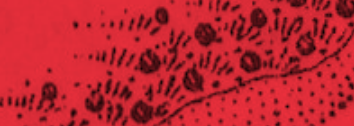

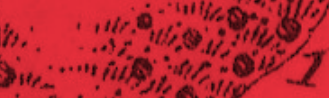

ing

is

ingising

sition

and!

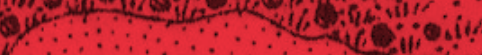

.

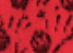

(2)
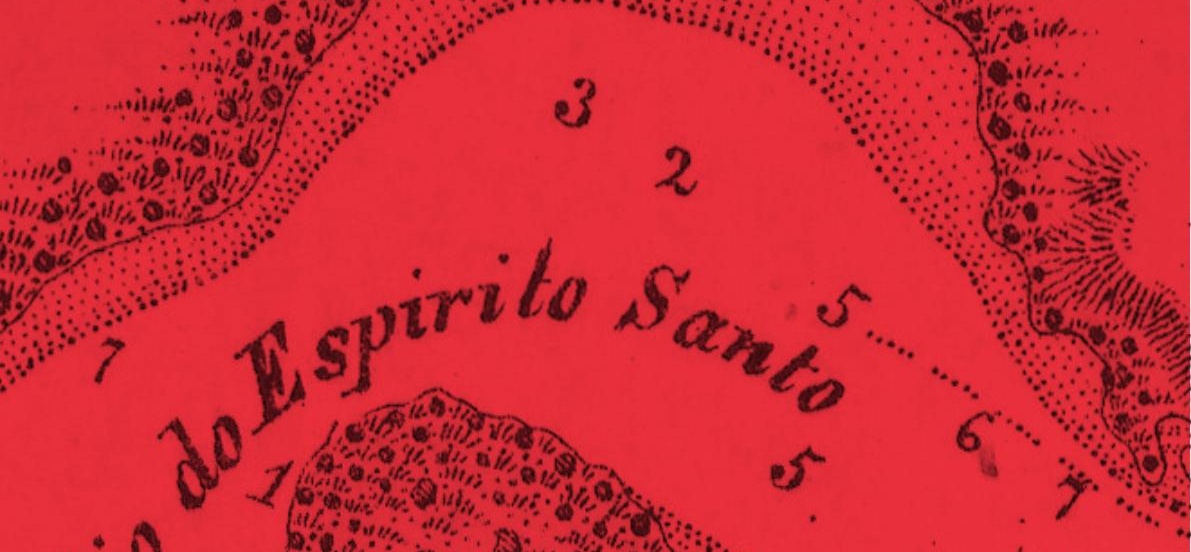

ivis 2,3

itis $y$

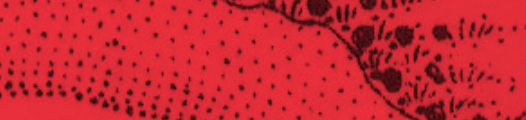

$M$

vilike

$\therefore$

28 istom.

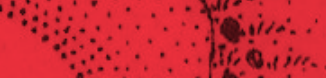

$6 \%$
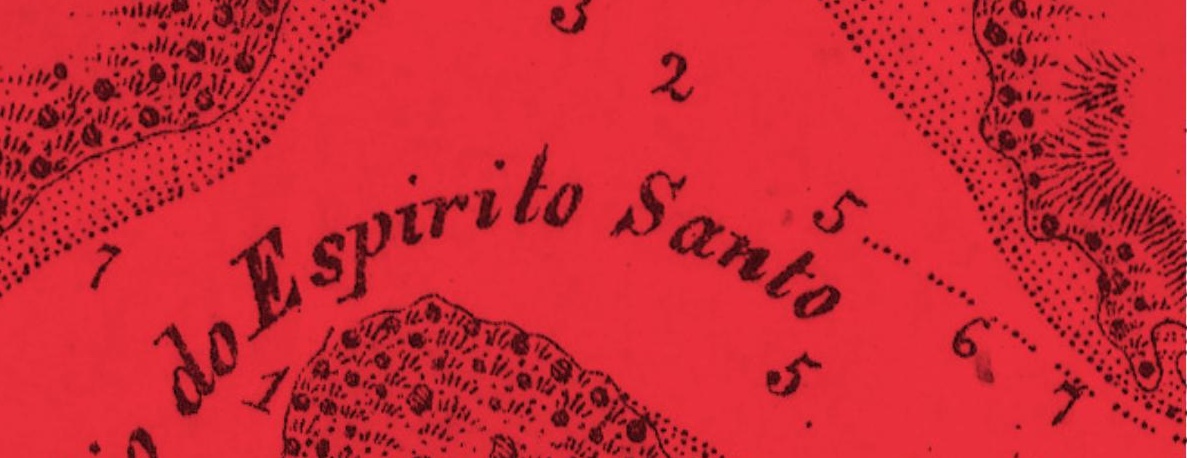

$2 \quad \because \because 20)$

3

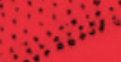
20 (2)

24

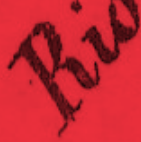

90.

A

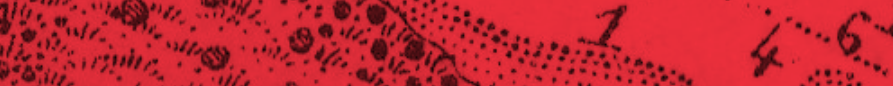

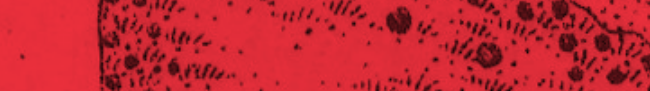

4

sive

sing

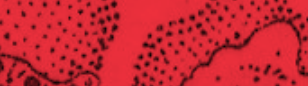

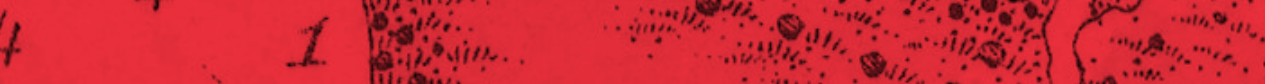

Detalhe com a inscrição ao território Mapfumo do Plan De La Baie De Lourenco Marques, 1873. Sobreposta a mancha atual do Bairro da Mafalala. 
O património condensado neste espaço encerra em si uma parte relevante da história de Moçambique. A subtileza com que se evidencia a riqueza cultural deste bairro está presente em cada detalhe urbano das ruas sinuosas que o caracterizam, onde facilmente nos perdemos na diversidade de influências culturais que as construíram. 


\section{0 impacto da xillunguíne nas comunidades africanas}

Com a instalação da capitalidade de Moçambique em Lourenço Marques, na transição entre os séculos XIX e XX, começaram a surgir as primeiras zonas suburbanas, onde se foram aglomerando os povos de origem africana. Não só os naturais dos territórios envolventes da baía, os tsongas ${ }^{2}$, predominantemente das chefaturas Mpfumu, como os provenientes de Moçambique. Mas o magnetismo da cidade nem sempre correspondeu às expectativas desses povos, tendo contribuído para a sua desagregação social e desenraizamento do meio rural e tradicional de onde provinham. Por outro lado, a xilunguíne reforçou a imagem do poder colonial, em particular para os povos a sul do rio Save, amenizando as convicções destes de expulsarem os invasores e embrenhando-os, cada vez mais, na trama do sistema colonial, algo comum em outras cidades coloniais africanas (Njoh, 2007: 1-3). Desta forma, os africanos foram sendo compelidos para uma economia liberal de matriz europeia e, neste caso, urbana, através de legislação tributária e coerciva, como o Imposto de Palhota, forçando-os, caso não pudessem pagar em dinheiro, ao trabalho assalariado, de matriz esclavagista, para assim poderem habitar ou cultivar as terras que antes Ihes pertenciam.

Face ao crescimento exponencial das cidades, alguns agregados familiares africanos adaptaram-se melhor a esta nova economia e prosperaram com ela, em especial os que produziam e vendiam produtos agrícolas para os florescentes mercados urbanos. 0 mesmo não se aplicava às famílias que tinham um homem emigrado durante meses ou anos nas minas ou plantações sul-africanas. O fluxo migratório masculino sobrecarregava as mulheres com encargos redobrados na logística familiar até ao regresso dos parceiros que, caso não morressem nas duras condições de trabalho a que eram expostos, voltavam frequentemente doentes. Estas e outras adversidades da vida citadina, como a escassez de terra para agricultura de subsistência e o difícil e caro acesso à água e à habitação, complicavam a fixação e adaptação dos africanos que se foram acumulando nos arrabaldes citadinos.

O surgimento, crescimento e impacto social dos subúrbios da 


\section{As origens da segregação urbana}

As medidas segregacionistas para com as comunidades africanas, em particular, e não europeias, em geral, seguiam não só a narrativa colonial da missão civilizadora como também incorporavam o discurso higienista desenvolvido ao longo do século XIX nos países do Norte. Em meados desse século, o esventramento de Paris segundo os planos do Barão de Haussmann, para criar um centro mais arejado e luminoso para a burguesia emergente, expulsou para as periferias as classes mais desfavorecidas que aí viviam. Salvaguardando as devidas proporções, veja-se o paralelo nas palavras de Augusto de Castilho sobre as causas e consequências de um incêndio que atingiu a xilunguíne de Lourenço Marques, em 1875: "as palhotas que eram mais densamente numerosas e mesmo muito mais infectas do que os preceitos da boa hygiene o permitiam, foram para sempre banidas do recinto das muralhas" (Castilho, 1880: 8). Nessa época, também em Portugal a resolução das irregularidades urbanas e habitacionais focavam problemas sanitários, tendo inclusive sido legislada a possibilidade de expropriar e destruir casas de bairros insalubres como, por exemplo,

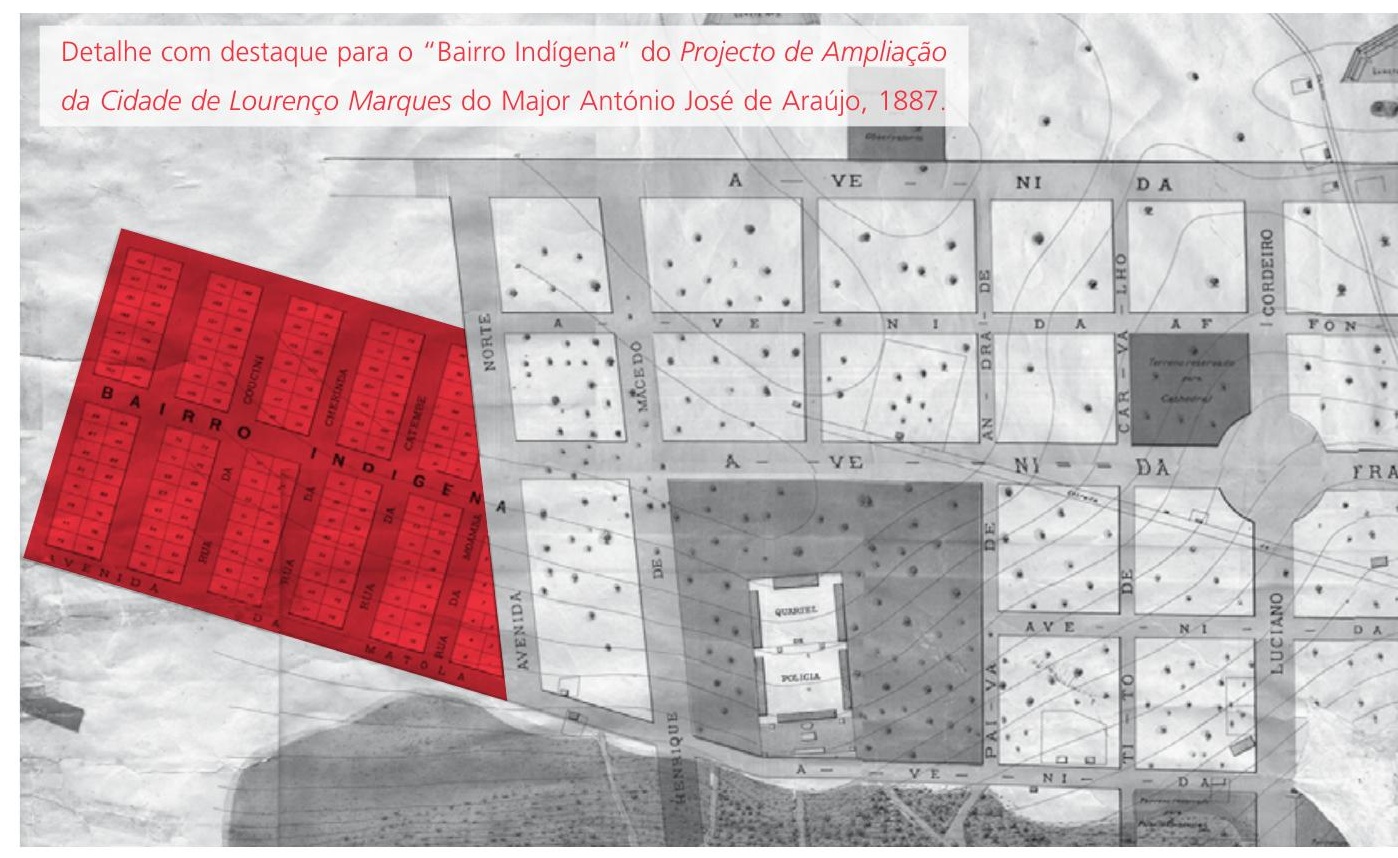


as ilhas do Porto (Gros, 1982: 10-11). Adaptar estes procedimentos urbanísticos às cidades dos territórios ocupados em África foi uma prática comum do colonialismo europeu.

A exploração mineira do Transvaal e o consequente desenvolvimento industrial levaram ao aumento dos fluxos migratórios de e para Lourenço Marques, expondo os seus habitantes a epidemias. As más condições de salubridade a que a mão de obra africana estava sujeita, tanto no trabalho como nas residências, eram campo fértil para a propagação de doenças, muitas delas pouco comuns ou mesmo inexistentes antes da ocupação europeia. O sanitation syndrome vai ser preponderante para as políticas urbanas coloniais na região, principalmente nas cidades mineiras do hinterland colonial britânico. Por osmose as cidades fornecedoras de mão de obra e serviços às anteriores, como Lourenço Marques, seguiram as mesmas diretrizes higienistas de cariz segregacionista, apesar de aí não serem aplicadas com tanto rigor. Para o efeito foram esboçados vários argumentos legais, como testemunham as intenções do relatório sobre o "problema da habitação indígena", elaborado em 1909 pelo Serviço de Saúde de Lourenço Marques:

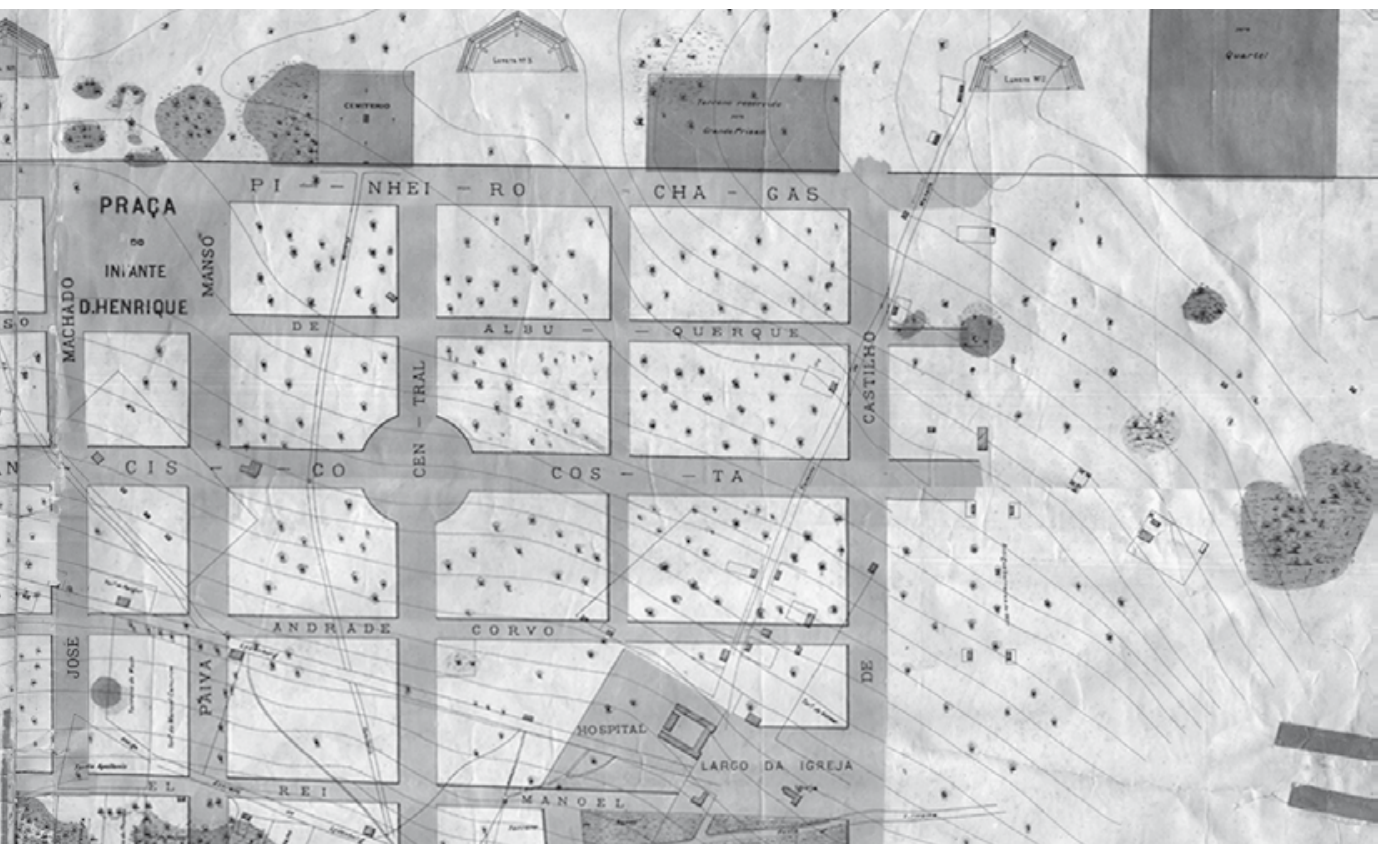


A acumulação em que vivem pretos, índios e chineses, em casas que são verdadeiros antros, com os hábitos de imundície que os caracterizam, constitui um dos mais poderosos elementos de insalubridade urbana e é um perigo permanente sob o ponto de vista do alastramento de qualquer epidemia. [...] Aqueles que ficam agora sem casa, procurarão em breve [...] instalar-se nos terrenos suburbanos, disseminando sem ordem e sem critério as suas moradias, de modo a cingirem a cidade de focos de infeção, dificilmente policiáveis. Seria de uma grande conveniência para a higiene de Lourenço Marques que nos subúrbios da cidade fosse escolhido um local conveniente para o estabelecimento de uma povoação para indígenas e outra para asiáticos. Nessas povoações, que deveriam obedecer a um plano previamente estudado, permitir-se-ia a construção de palhotas ou de casas rudimentares de madeira e zinco, sendo proibidas as edificações de alvenaria. Esta proibição teria por fim poder-se destruir facilmente a povoação, ou parte dela, rapidamente sem grandes prejuízos quando disso houvesse uma imperiosa necessidade ${ }^{5}$. [...] Aos indígenas, a proibição de habitarem dentro da cidade estender-se-ia a todos, com exceção dos que, pelas suas condições sociais e modo de vida, merecessem tratamento especial, e dos serventes que vivessem na casa dos seus patrões. (Lourenço Marques Guardian, 1909)

O relatório demonstra as intenções da administração colonial de isolar os povos não-europeus nos subúrbios através de argumentos higienistas, propondo a construção de bairros específicos para não-europeus separados do resto da cidade, à semelhança das native locations $^{6}$ sul-africanas. A intenção já estava patente no Projeto de Ampliação da Cidade, elaborado em 1887 pelo Major António José de Araújo, mas foi sendo adiada até à construção dos bairros para indígenas do Xipamanine e da Munhuana. A estruturação urbana da cidade, como a conhecemos hoje, ficaria completa logo em 1903, quando foi traçada a circunvalação ${ }^{7}$. À exceção de alguns serventes domésticos que eram alojados em dependências nos quintais das casas ou lojas dos patrões, os restantes africanos foram compelidos a estabelecerem-se nos terrenos baldios exteriores à circunvalação. Estas medidas legais preocupavam-se mais com o controlo dos movimentos destas pessoas do que com a regulação 
e combate à insalubridade local. A ausência de investimento em infraestruturas viárias e sanitárias nos subúrbios refletia "o carácter tradicionalmente especulativo da burguesia portuguesa" da época que, em termos urbanos e à semelhança do que acontecia no reino, estava pouco interessada "em investir em trabalhos de infraestrutura e equipamentos demorados e custosos" (Gros, 1982: 11-12). Por outro lado, na xilunguíne a administração colonial era mais zelosa de forma a assegurar uma salubridade próxima dos standards europeus, com o intuito de atrair e manter os colonos na cidade. Apesar da iniquidade de critérios do município na infraestruturação dentro e fora dos "marcos da cidade"8, a tributação predial era igual em ambos os lados (Nyeleti, 1912: 1), o que se manteve praticamente até à independência.

\section{A propriedade do solo e a especulação imobiliária}

Com o desenvolvimento da urbe o valor do solo aumentou no âmbito de uma intensificação da especulação imobiliária. A administração colonial portuguesa tentou controlar o processo desde meados do século XIX, mas o deixa-andar dominante e a condescendência e incapacidade das autoridades perante o fenómeno, goraram os resultados esperados. Aproveitando o pouco rigor legal e institucional, os especuladores imobiliários foram adquirindo grandes áreas de terrenos suburbanos às chefaturas Mpfumu. Os investidores eram maioritáriamente estrangeiros atentos ao progresso da cidade, causado essencialmente pelo crescimento económico das colónias anglo-boers vizinhas e da ligação ferroviária que a unia a estes territórios.

Algumas destas transações imobiliárias entre os Mpfumu e os estrangeiros tiveram origem em redes comerciais de tempos mais recuados, sendo comum a união de facto ou matrimonial como forma de selar os negócios fundiários, o que tornava mais difícil o já parco controlo das autoridades coloniais. Numa tentativa de regularizar a situação, a administração colonial ordenou a execução de um levantamento cadastral ${ }^{9}$ dos terrenos da cidade e arredores, não só para controlar a especulação imobiliária estrangeira como também para preparar a derradeira ocupação do território Mpfumu. 


\section{A ocupação efetiva do território Mpfumu}

O missionário suíço Henri-Alexandre Junod, que privou com os Mpfumu nessa época, levantou a questão: "Que deviendra la race noire, la légitime propriétaire de ces territoires convoités, annexés et bientôt occupés par les Blancs?"10 (Junod, 1898: 10). A resposta iria surgir, em 1909, com a aprovação do Regime provisório para a concessão de terrenos do Estado na província de Moçambique, que ditou a perda dos direitos de posse de terra da maioria dos povos nativos da colónia a favor dos colonos europeus. O decreto ${ }^{11}$, de 9 de julho de 1909, classificou povoações "de carácter europeu" e nacionalizou a propriedade fundiária não reconhecida pela legislação portuguesa, o que excluía praticamente todos os povos autóctones do direito à posse das suas próprias terras e o não reconhecimento dos seus povoados preexistentes. Desta forma, à maioria dos indígenas passou a ser permitida apenas a ocupação de reservas criadas exclusivamente para eles, mas sobre as quais não tinham direito de propriedade. Esta lei fazia parte da trama legal atrás referida que, à semelhança do que vinha a ser praticado em outras colónias europeias em África (Njoh, 2007: 73-78), servia a fórmula essencial para proletarizar coercivamente os africanos. Por um lado, obrigava-os a pagar impostos, por outro restringia-lhes o acesso à propriedade fundiária, compelindo-os desta forma para o trabalho assalariado cada vez mais abundante nas zonas urbanizadas. Depois da implementação deste instrumento legal grande parte dos nativos, como os Mpfumu, passaram de legítimos e ancestrais proprietários a clandestinos sujeitos às imposições legais dos colonizadores. A partir daqui, caso quisessem continuar a viver ou a explorar as suas terras, tinham de pagar renda a terra-tenentes, maioritariamente não-africanos.

\section{0 início da estrutura urbana dos subúrbios}

Em termos geográficos o decreto de 9 de julho de 1909 iria estratificar a cidade através de três arcos concêntricos num ponto situado junto da Praça 7 de Março, atual 25 de Junho. O arco central, já visível em alguma cartografia do início do século XX, viria a circunscrever a 
xilunguíne com um raio de $2 \mathrm{~km}$. À semelhança das políticas urbanas que vinham sendo aplicadas nas duas principais cidades da metrópole, Lisboa e Porto, a "linha de circumvallação"12 tinha como função essencial evitar o "descaminho de direitos da Fazenda Nacional"13. $\mathrm{Na}$ capital de Moçambique a circunvalação, além de funcionar como linha de fiscalização tributária da cidade, teve também uma intenção defensiva em relação a possíveis novas rebeliões indígenas. Por outro lado, esta linha pretendia estruturar a malha urbana ortogonal projetada no Plano Araújo ${ }^{14}$ através de um arco que ligasse o Palácio do Governador, na Ponta Vermelha a este, à Estação Ferroviária a oeste na frente ribeirinha. Foi definida uma zona de expansão da cidade que, na realidade, funcionava como separação ${ }^{15}$ em relação aos subúrbios, com um quilómetro para o exterior do arco, ou seja, num raio de $3 \mathrm{~km}$ a partir do centro original. É interessante observar que o mesmo raio, desta vez com o centro da Praça do Comércio, foi utilizado para definir a circunvalação de Lisboa, em 1885, o que denota a semelhança de critérios urbanos utilizados na metrópole e na colónia. Só que aí o fator colonial enfatizou a fronteira entre o centro, europeu, e o subúrbio, africano. Esta estratificação radial e racial do espaço urbano também esteve presente no planeamento de cidades como Kimberley ou Johannesburg, apesar daí não se ter materializado de forma tão vincada na estrutura urbana. De qualquer forma, tanto nos exemplos sul-africanos como na capital de Moçambique, o recurso à radialidade no desenho urbano foi utilizado para controlar os movimentos dos indígenas, segregando-os a uma distância suficientemente segura da zona central, predominantemente europeia, mas não demasiado longe dos postos de trabalho onde eram necessários (Frescura, 2000: 5-6).

Planta da cidade de Lisboa e seus arredores, c.1885. Sobreposta a circunvalação com um raio de $3 \mathrm{Km}$ com centro na Praça do Comércio.

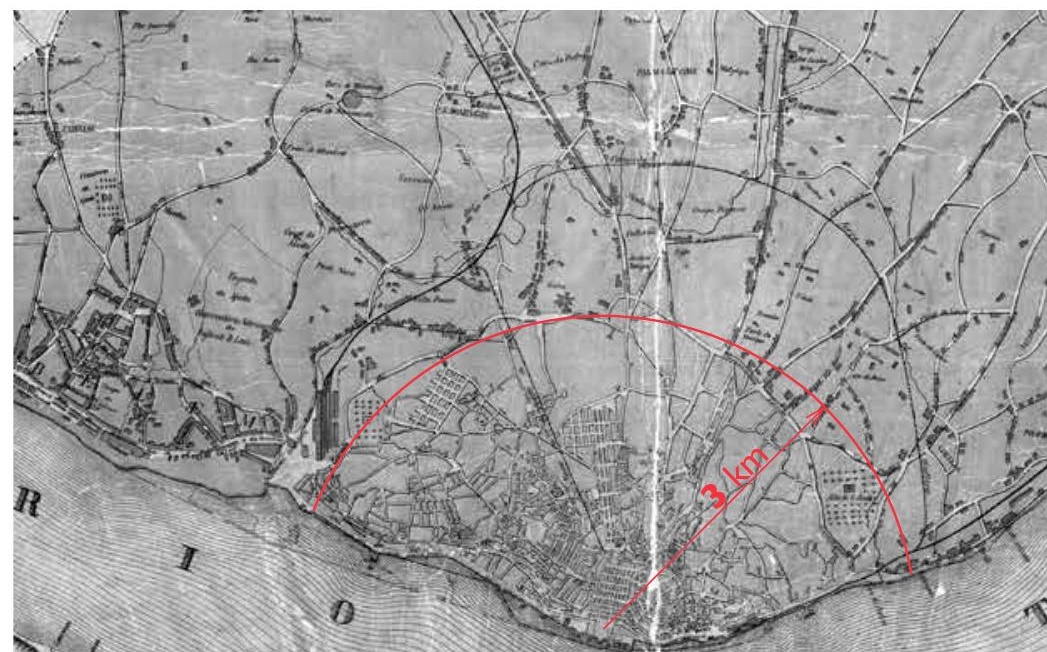




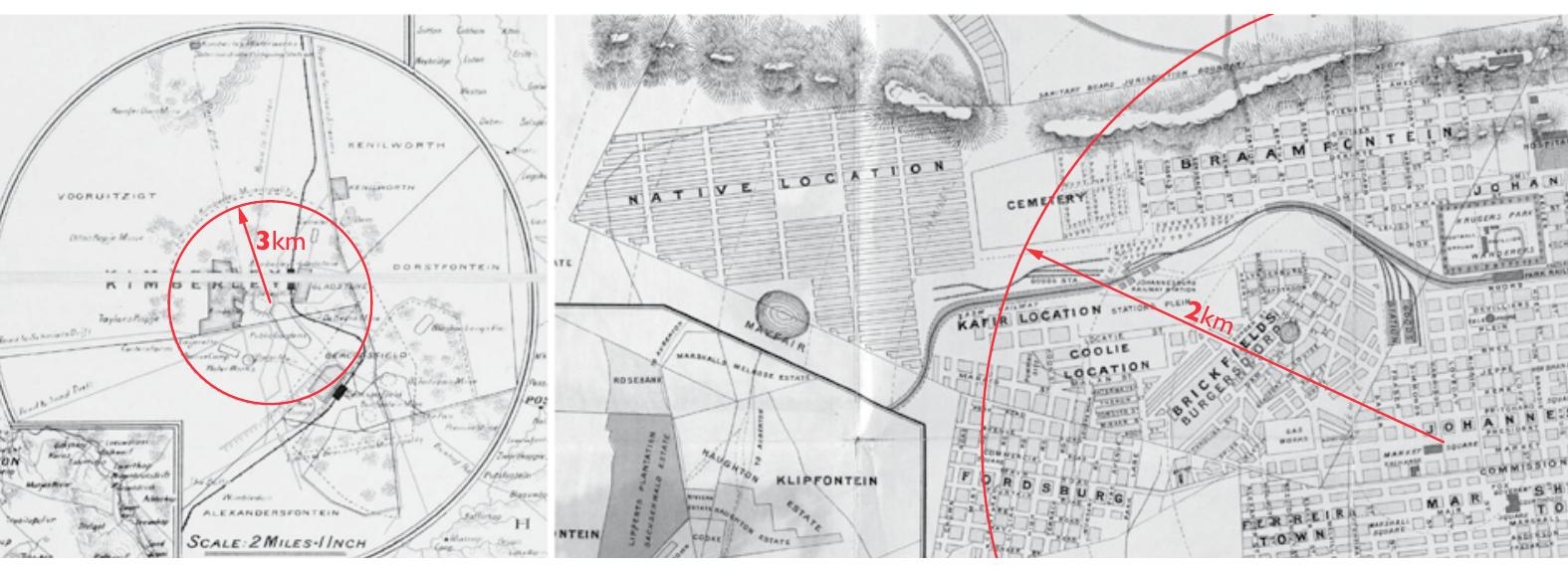

Planeamento urbano radial na África do Sul no final do século XIX.

À esq. ${ }^{a}$ detalhe da planta de Kimberley do mapa Briton or Boer,

1900. À dir. a detalhe do Plan of Johannesburg and suburbs, 1897

No caso de Lourenço Marques a zona de expansão, ou de tampão, só viria a ser respeitada nos dois bairros para indígenas projetados e construídos pelo município: o do Xipamanine, construído entre 1918 e 1921, e o da Munhuana, entre 1938 e 1942. Estes bairros foram implantados no limite exterior do arco dos $3 \mathrm{~km}$ : a noroeste, nas zonas do Chamanculo, Xipamanine e Zixaxa; a norte, na Munhuana e Malhangalene, a que pertencia a Mafalala. Esta última zona acabou por não ser respeitada devido aos assentamentos espontâneos de povos africanos que aí se foram adensando, pelo facto da expansão da xilunguíne não ter seguido essa direção. O desenvolvimento urbano da cidade branca acompanhou os flancos costeiros mais ventilados a este, pelo eixo Polana-Sommerschield, e, a sul, no prolongamento da Avenida 24 de Julho, na atual zona da Malanga. A proximidade com o Porto, Caminho de Ferro de Lourenço Marques [PCFLM] e a Estrada de Lydenburg gerou um corredor de desenvolvimento em direção ao hinterland sul-africano, no final do século XIX.

Nessa época, a relação com as Terras do Estado (antigas Terras da Coroa), a norte, era pouco relevante para o desenvolvimento económico da cidade, ao contrário do que acontecia com o Transvaal, o seu motor de crescimento. Isto fez com que as zonas do Chamanculo, Zixaxa, Munhuana e Malhangalene tivessem um desenvolvimento mais lento, tornando os seus terrenos e respetivos proprietários expectantes em 


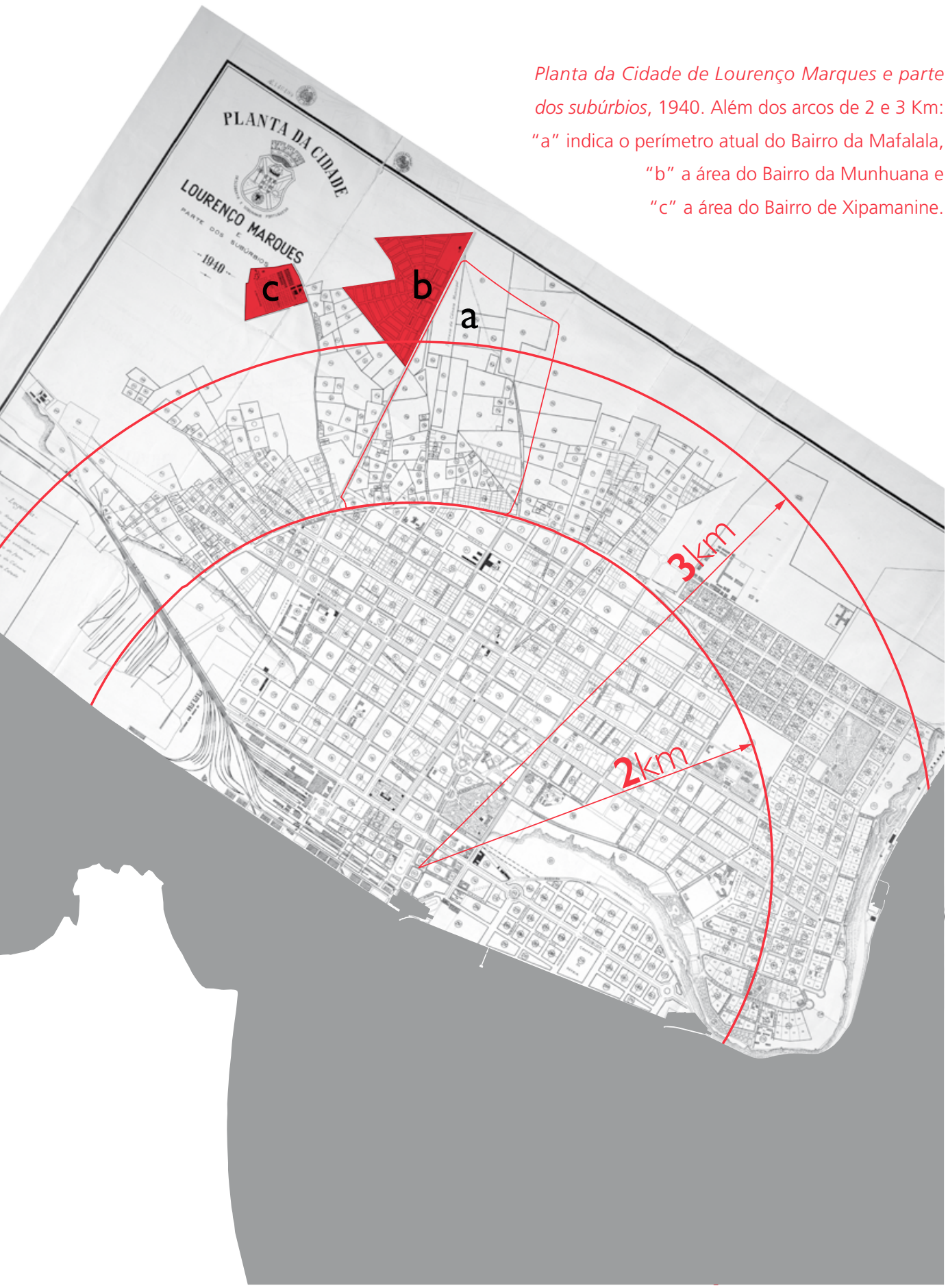


relação ao desenvolvimento e expansão da cidade naquela direção. Foi nestes terrenos que grande parte das populações indígenas se concentraram de forma espontânea, precária e, muitas vezes, ilegal.

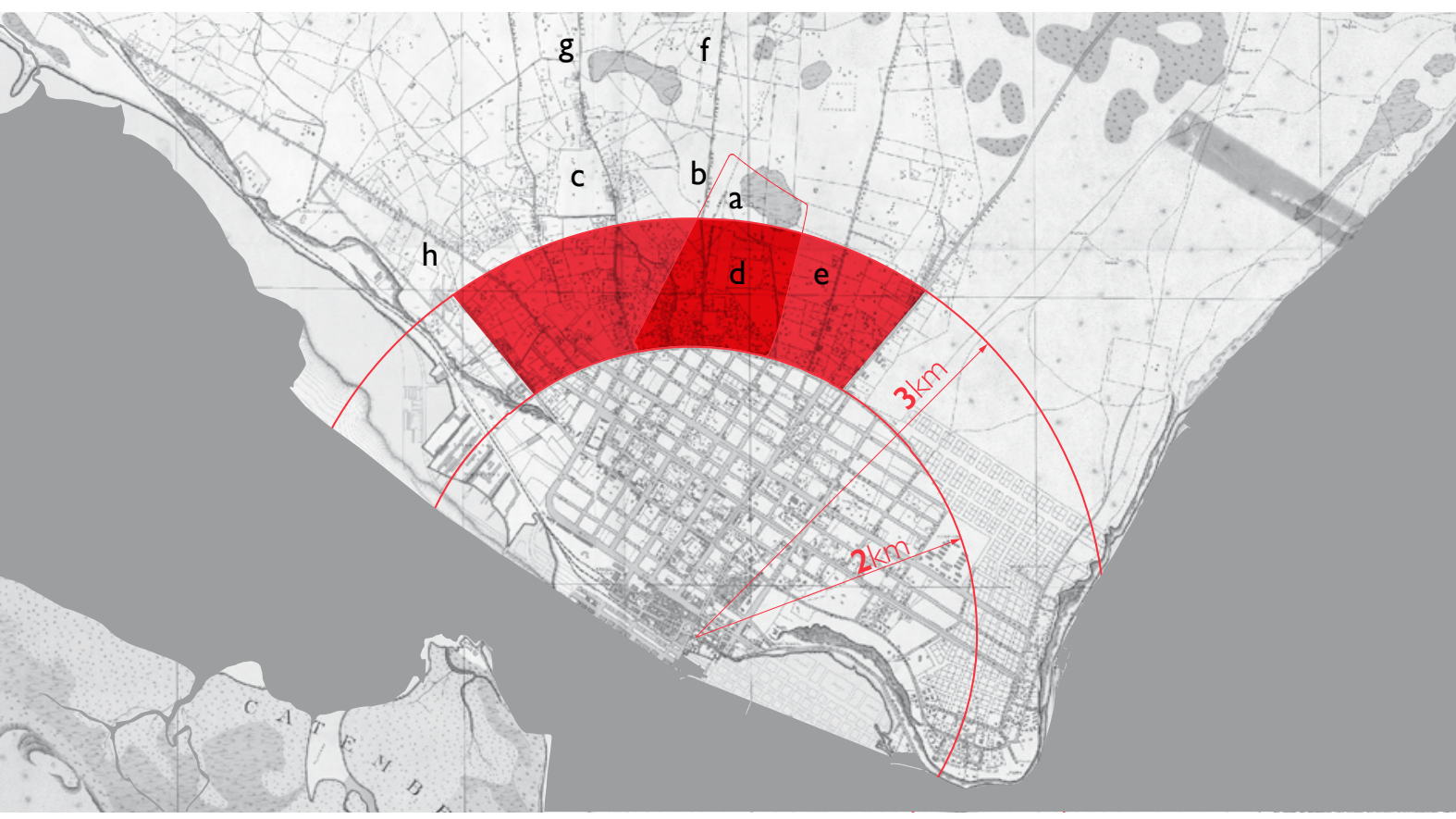

Detalhe da Planta da Cidade de Lourenço Marques e subúrbio por E. de Moctezuma, 1907-1912. Além dos arcos de 2 e $3 \mathrm{Km}$ : "a" indica o perímetro atual do Bairro da Mafalala, "b" a área do Bairro da Munhuana, " $c$ " a área do Bairro de Xipamanine, " $d$ " o ponto de génese do Bairro da Mafalala, "e" a Zona de expansão segundo o Decreto de 09/07/1909, " $f$ " a antiga estrada para as Terras do Estado (atual Rua de Goa), "g" a antiga estrada de Xixara (atual Rua dos Irmãos Roby) e " $h "$ a antiga estrada de Lydenburg.

Em termos urbanos os fatores descritos interagiram com o traçado urbano e o parcelário que caracteriza os subúrbios da cidade, em particular, o território onde se veio a definir a Mafalala. A irregularidade ou informalidade do tecido suburbano teve parte da sua origem no cadastro fundiário do início do século XX, que foi cartografado pelos serviços de agrimensura na Planta da Cidade de Lourenço Marques e Subúrbios em 1912, onde já é visível a diferença entre a malha urbana interior e exterior à circunvalação. 


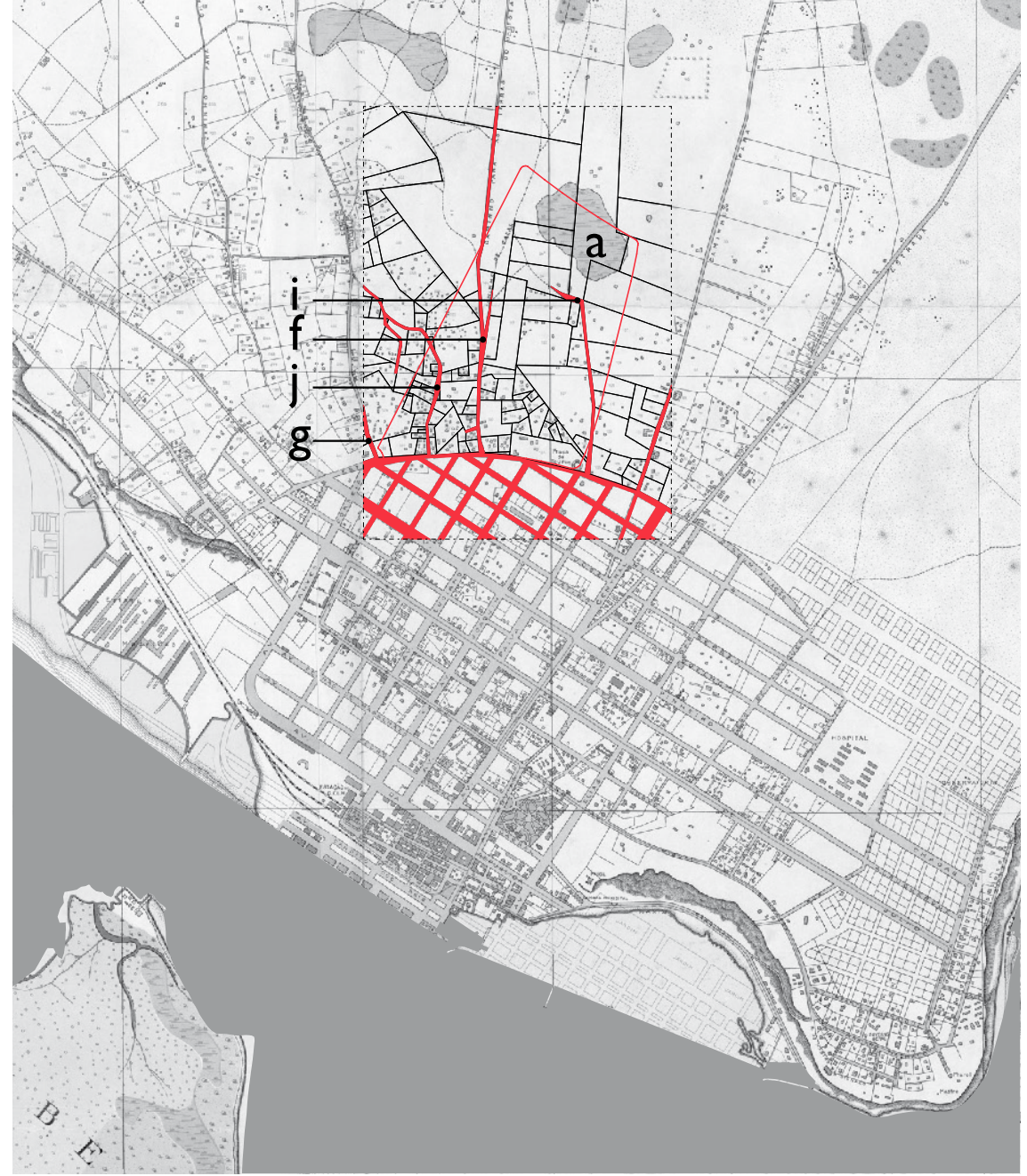

Detalhe da Planta da Cidade de Lourenço Marques e subúrbio por E. de Moctezuma, 19071912. "a" indica o perímetro atual do Bairro da Mafalala, " $f$ " a antiga estrada para as Terras do Estado (atual Rua de Goa), "g" a antiga estrada de Xixara (atual Rua dos Irmãos Roby), "i" caminho que deu origem à atual Rua de Timor e "j" caminho que originou a atual Rua da Guiné.

Formalmente a diferença residia, e ainda reside, no pragmatismo da malha ortogonal proposta pelo Plano Araújo, em contraste com a malha urbana, mais orgânica, que surge do lado exterior da radial. Conforme se observa num título de concessão de um terreno na Mafalala, datado de 1911, os perímetros das parcelas ${ }^{16}$ extra circunvalação vão definir a malha suburbana. Comparando o perímetro da parcela 187 e respetivas confinantes com a evolução da malha urbana na mesma zona, verifica-se que os perímetros se mantêm praticamente inalterados até ao presente. Este elemento confirma um dos princípios básicos do urbanísmo apurado pelos estudos de morfologia urbana, o da lei da persistência do plano. 


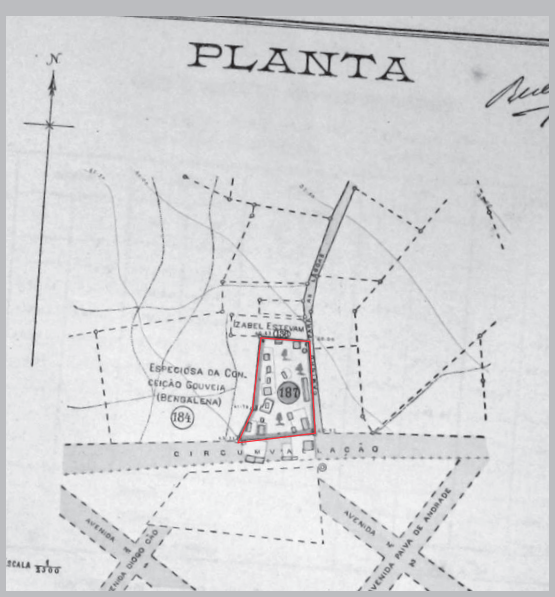

1911

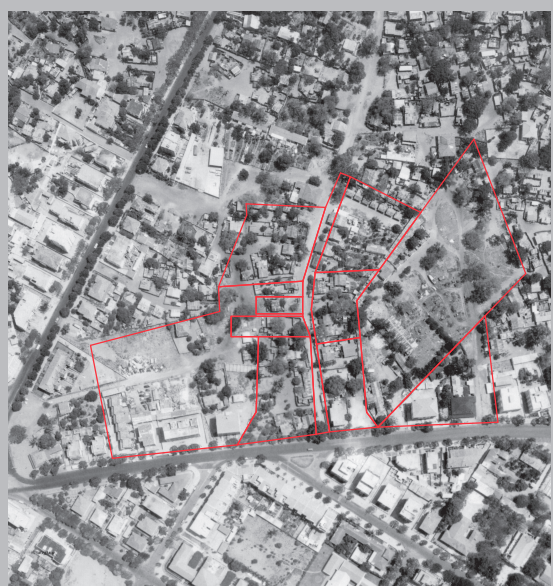
1966

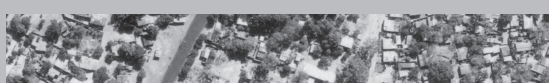

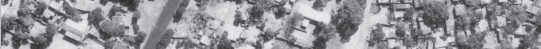

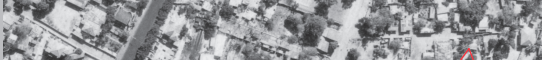

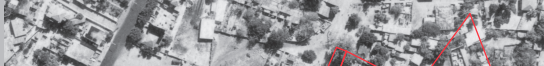

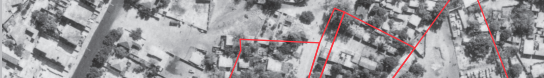

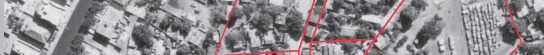

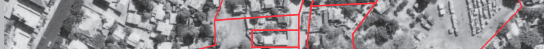

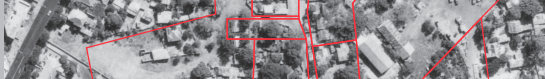
SI 1 -

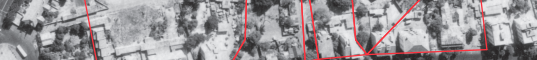

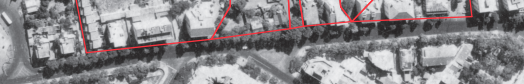

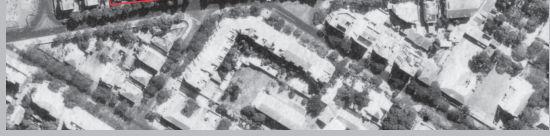
1979

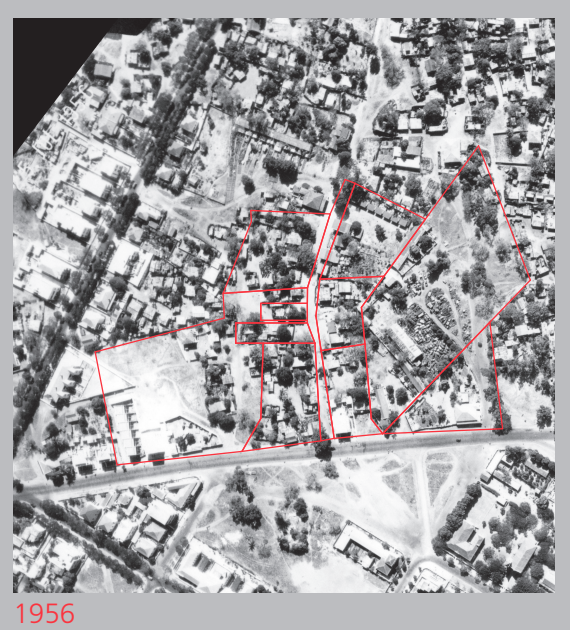

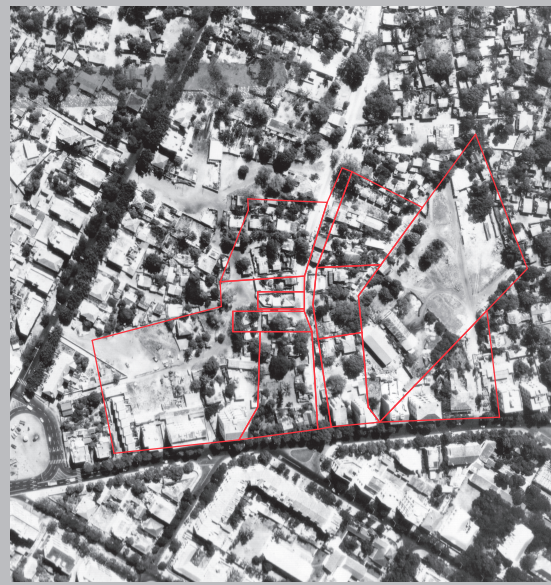
1973

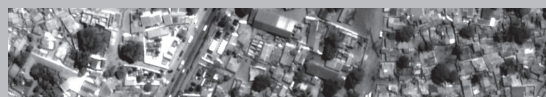

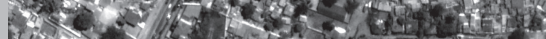

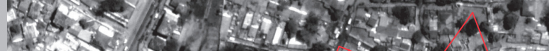

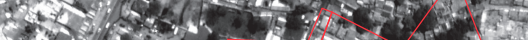

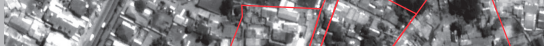

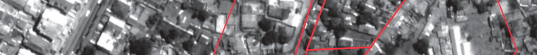

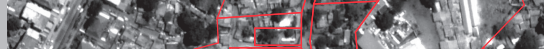

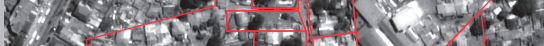

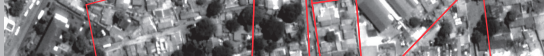

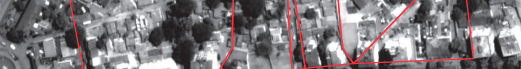

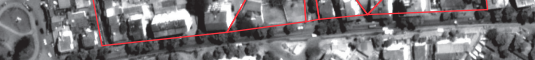

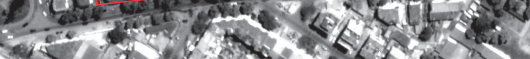

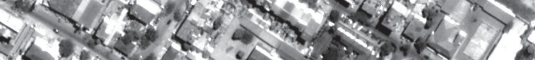

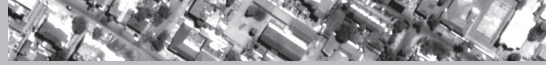
2015 
Este fenómeno urbano explica-se, em parte, pela forma como a maioria das parcelas dos subúrbios, localizados entre os arcos dos dois e três quilómetros, foram sendo ocupadas. Conforme já mencionado, enquanto os seus proprietários aguardavam, expectantes, a expansão da xilunguíne para depois revenderem a preços especulativos, as populações africanas foram ocupando espontânea e provisoriamente cada parcela, condensando-se dentro dos respetivos perímetros segundo lógicas urbanas próprias, à margem da administração colonial, que mantinha uma atitude de deixa-andar, condescendente perante a informalidade fundiária e auto reguladora dos subúrbios (Mitchell, 1975: xii-xiii). Essa atitude contrastava com o rigor legislativo que se tentava impor na cidade formal, onde os órgãos municipais estavam mais atentos e ativos na aplicação e fiscalização dos instrumentos legais, tentando assegurar que o crescimento urbano se mantivesse confinado à malha ortogonal traçada pelo Plano Araújo.

A dualidade de critérios no tratamento da xilunguíne e do caniço vai acentuar a dicotomia urbana vincada pela circunvalação, apesar de, em ambos os lados dessa fronteira, o desenho do tecido urbano ser definido pelos perímetros das parcelas preexistentes. Todavia, a disparidade geométrica destes perímetros, a forma como a sua ocupação se processou e foi, ou não, regulada, e as discrepâncias socioeconómicas dos seus ocupantes, marcaram a diferença formal entre os dois espaços.

A geometria irregular do traçado suburbano da capital moçambicana resultou não só dos perímetros parcelares, mas também dos percursos de pé posto, definidos pelo quotidiano dos seus habitantes, e pelos interstícios entre as construções fragmentárias, e sem plano, que iam preenchendo cada parcela. Estes processos espontâneos, comuns em outros espaços suburbanos, como as favelas brasileiras (Jacques, 2001), resultaram no labiríntico sistema de ruas e vielas que caraterizam o espaço urbano de bairros como a Mafalala. 


\section{A proximidade laboral e a segmentação dos subúrbios}

O trabalho foi uma "forma estruturadora das relações quotidianas entre o colonialismo português e as populações colonizadas" (Jerónimo e Domingos, 2015: 139) e, neste sentido, a geografia laboral da cidade era um fator determinante na fixação das comunidades africanas nos subúrbios. Este fator foi contribuindo para a caracterização urbana, cultural, social e política de cada um dos bairros, em que as rendas eram mais elevadas nas zonas próximas dos limites da circunvalação, remetendo aos espaços mais recônditos as populações com menor capacidade económica.

O fenómeno não é tão visível na distribuição dos tsongas da baía, em particular os das chefaturas Mpfumu, pois eram os habitantes naturais daquele território, sendo a sua presença transversal a todos os subúrbios. Mesmo depois do esbulho colonial das suas terras, uma minoria ainda preservou pequenas parcelas (Penvenne, 1993: 102-107). Alguns foram, inclusivamente, escolhidos pela administração colonial para regedores de zonas suburbanas. Já os habitantes de outras proveniências que migraram para os subúrbios da capital, em busca de trabalho e melhores condições de vida, tiveram tendência a se fixar e concentrar em zonas específicas de acordo com os seus locais de trabalho (Rita-Ferreira, 1968: 244). Os bairros Chamanculo e Xipamanine, por exemplo, devido à proximidade ao PCFLM e à estrada para Lydenburg, acolheram comunidades fornecedoras de mão de obra para os transportes pesados do porto e via-férrea bem como, para a mineração do Transvaal. Este operariado tendia para uma relação mais distante e, muitas vezes, conflituosa com as entidades empregadoras devido ao facto de trabalharem em massas laborais de maior dimensão, geradoras de um proletariado mais associativo, politizado e, consequentemente, reivindicativo (Penvenne, 1993: 66). Os povos do sul do rio Save foram os que mais emigraram para as minas do Transvaal, sendo o seu percurso normalmente via Lourenço Marques onde, enquanto estavam em trânsito, se concentravam, na sua maioria, junto dos acampamentos ou, como eram conhecidos na altura, dos compounds ${ }^{17}$ de engajadores de mão de obra como a Witwatersrand Native Labour Association [WNLA]. Por questões logísticas, esses compounds localizavam-se nas imediações do PCFLM, ou seja, nos bairros acima referidos. 
A agregação étnica nos subúrbios era semelhante à organização laboral das minas sul-africanas, onde os mineiros eram aquartelados nos compartimentos dos compounds segundo a sua etnia (Harries, 1989: 102). Este facto corrobora a forte influência das cidades anglo-boers na urbanidade da capital de Moçambique, em especial a importância do trabalho na localização dos habitantes suburbanos e seus quotidianos.

No caso da população que se fixou na zona da Mafalala, que aqui nos ocupa, a relação geográfica e laboral com a xilunguíne era mais diversificada. Apesar de haver quem trabalhasse nas minas sul-africanas e nos PCFLM, a proximidade com zonas comerciais, como o Alto Maé, residenciais e turísticas, como Sommerschield e Polana, atraiu para esta zona dos subúrbios comunidades ligadas ao setor terciário (Mendes, 1985: 445). As atividades laborais mais significativas eram: a prestação de serviços aos comerciantes, como empregados de lojas e cantinas, às residências, hotelaria e restauração, com serviços domésticos diversificados, como cozinheiros, mainatos, criados, moleques, muanas, entre outras designações utilizadas na época. Estes misteres tinham a particularidade de proporcionar uma maior interação com a sociedade colonial da xilunguíne. Na prestação de serviços domésticos a relação com a entidade patronal, apesar de não menos violenta e assimétrica, proporcionava uma maior proximidade às culturas não-africanas da cidade. Mesmo sendo praticamente invisíveis para os patrões, os empregados domésticos aprendiam mais sobre a cultura do colonizador do que este sobre a do colonizado (Cabaço, 2007: 185-191). Alguns chegavam a ter uma posição de relativa confiança perante os empregadores, proporcionando-lhes certas vantagens informais como, por exemplo, alguma proteção caso fossem apanhados pela "polícia do trabalho, a vadiarem sem documentos" (Penvenne, 1993: 58 e 163), ou até permissões especiais para circularem pelas ruas da xilunguíne fora das horas do "recolher obrigatório para indígenas" (Cabaço, 2007: 187-188) e assim se livrarem do chibalo. 

na sua maioria chineses e indianos ou baneanes, sendo estes últimos predominantemente muçulmanos, mas também hindus e católicos goeses (Sopa, 2014: 35). Este fenómeno vai fomentar a fixação no bairro de comunidades islamizadas provenientes da costa swahíli e ilhas do Índico, nomeadamente da llha de Moçambique, dando ao bairro um espectro cultural mais amplo em relação aos restantes subúrbios, constituídos essencialmente por povos do sul do rio Save. A variedade de proveniência geográfica, de atividades laborais e de diversidade cultural dos habitantes da Mafalala gerou redes e inter-relações socioculturais que fomentaram o aparecimento de comunidades culturalmente heterogéneas. A relação destas populações com a xilunguíne terá também contribuído para que surgissem no bairro distintas expressões culturais que se foram transformando em consciência política da condição colonial.

\section{0 espaço urbano da Mafalala}

\section{A descrição do bairro}

Bairro da Mafalala localiza-se dois quilómetros a norte do centro Maputo em pleno planalto onde se implantou a cidade alta a partir do primeiro quartel do século XX. Foi nessa época que começou a ganhar forma a atual configuração urbana do bairro, com o arco da circunvalação, atual Avenida Marien N'Gouabi, assumido como limite sul. Em meados do mesmo século, o restante perímetro foi delimitado nas laterais do sentido sul-norte, pela Avenida de Angola, a oeste, que confina com a Munhuana e atual Minkadjuine, e pela Avenida Acordos de Lusaka (antiga Craveiro Lopes), a este, que confronta com a Malhangalene. O limite norte definiu-se já no início do século XXI com a construção definitiva da Avenida Joaquim Chissano.

Em termos viários, o bairro tem dez entradas principais, sendo três a sul, quatro a oeste e três a este. As vias mais importantes e antigas são as ruas da Guiné e de Goa, que ligam, no sentido sul-norte, às avenidas Marien N'Gouabi e a de Angola. A norte desta última, as ruas de Angola e da Lixeira (antiga bucaria) ligam, no sentido oeste-este, com a Avenida Acordos de Lusaka, 


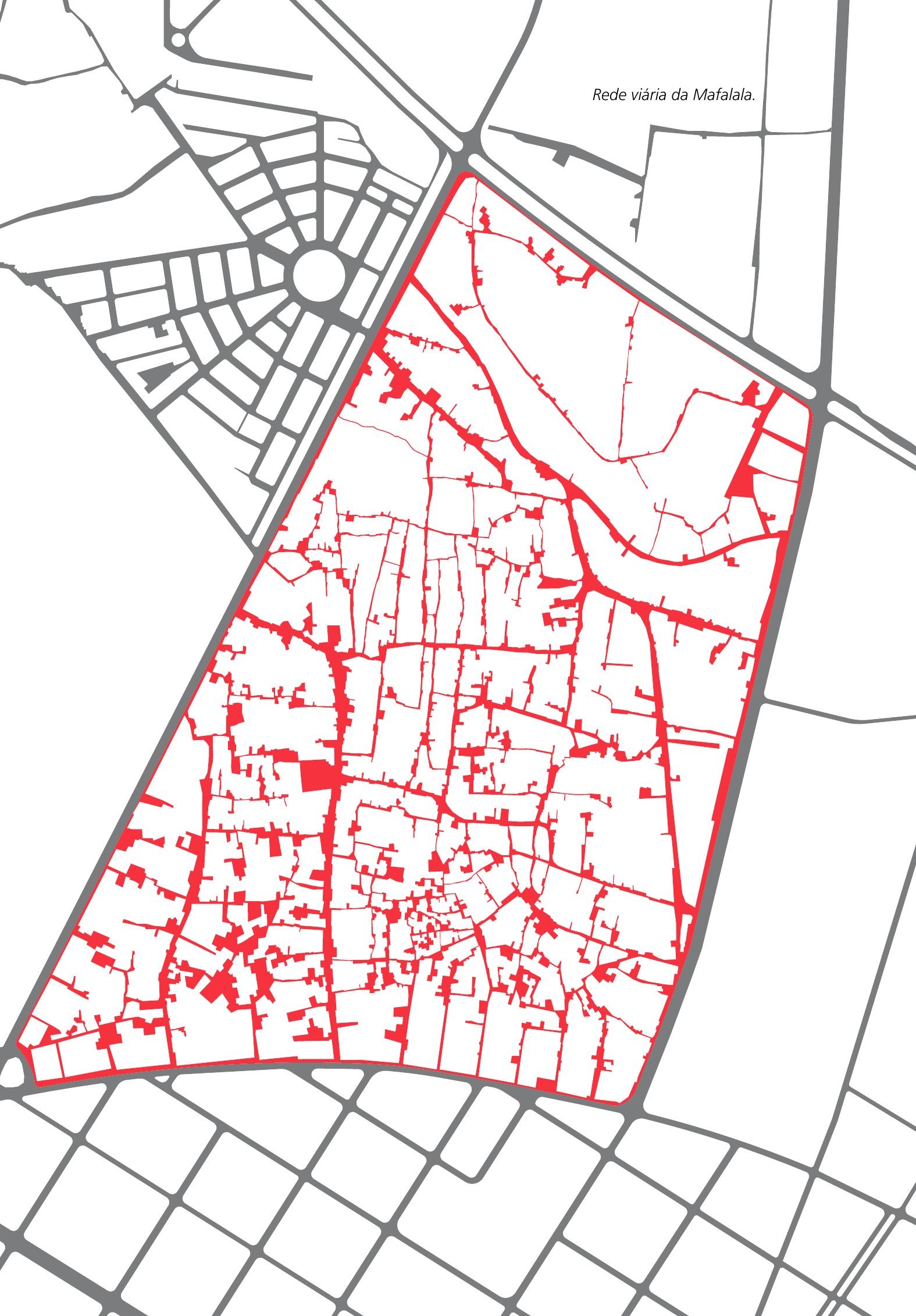




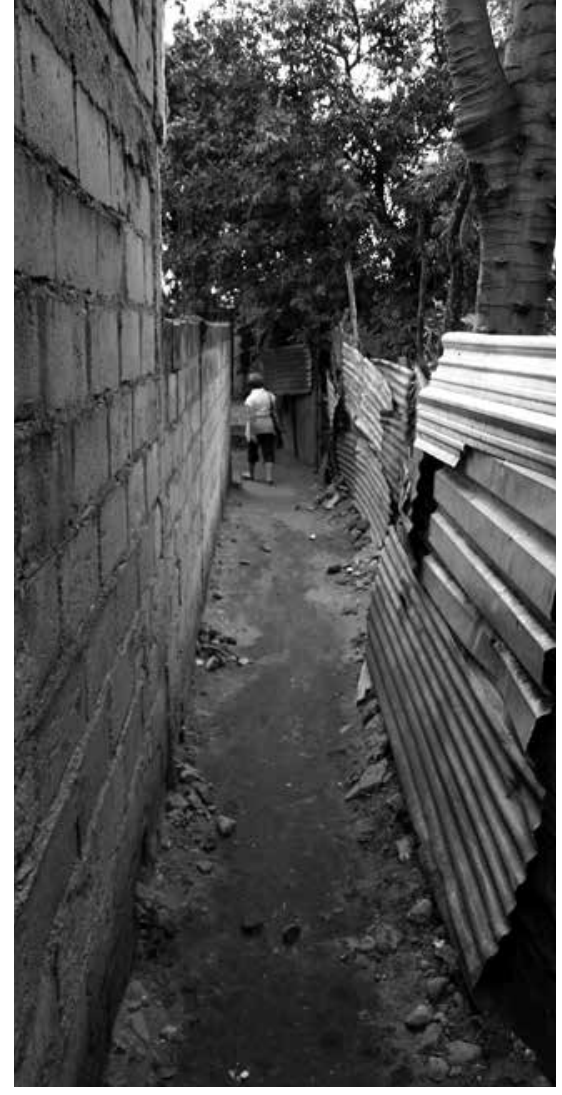

onde também intercetam as ruas de Timor, a Eusébio da Silva Ferreira e a Ivete Amós. Estas vias desmultiplicam-se internamente através de uma sinuosa e complexa rede acessos que penetram por entre o casario. Esta hierarquia viária faz lembrar o sistema circulatório de um corpo, que começa pelas principais artérias, como a Rua da Guiné, por exemplo, e se vai embrenhando para dentro do bairro até se transformar em estreitas vielas, como se fossem finos capilares $^{18}$ a alimentar os locais mais recônditos da Mafalala.

Largo junto à antiga casa de Samora Machel.

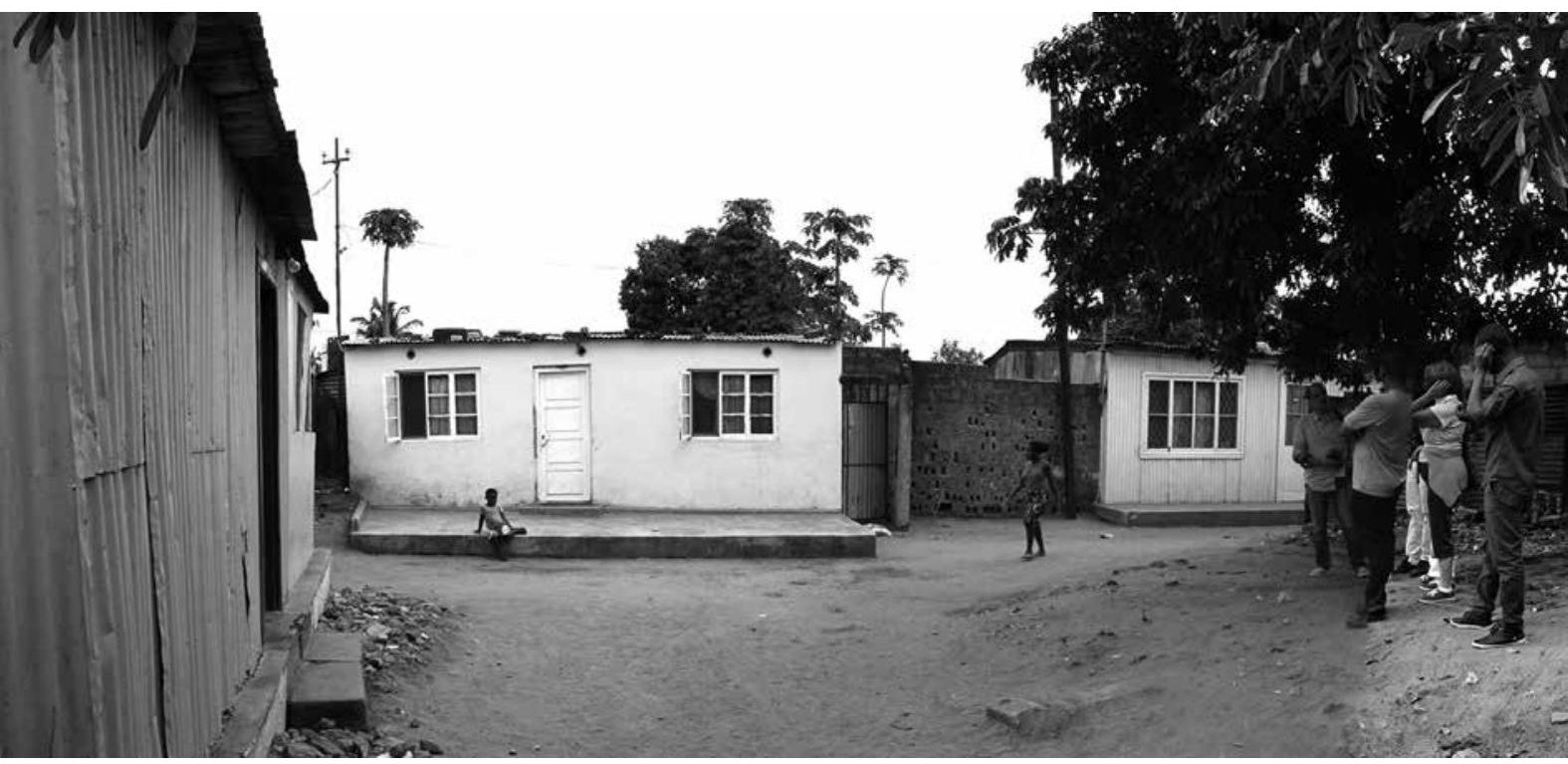


Pormenor do revestimento de uma habitação, 2013.

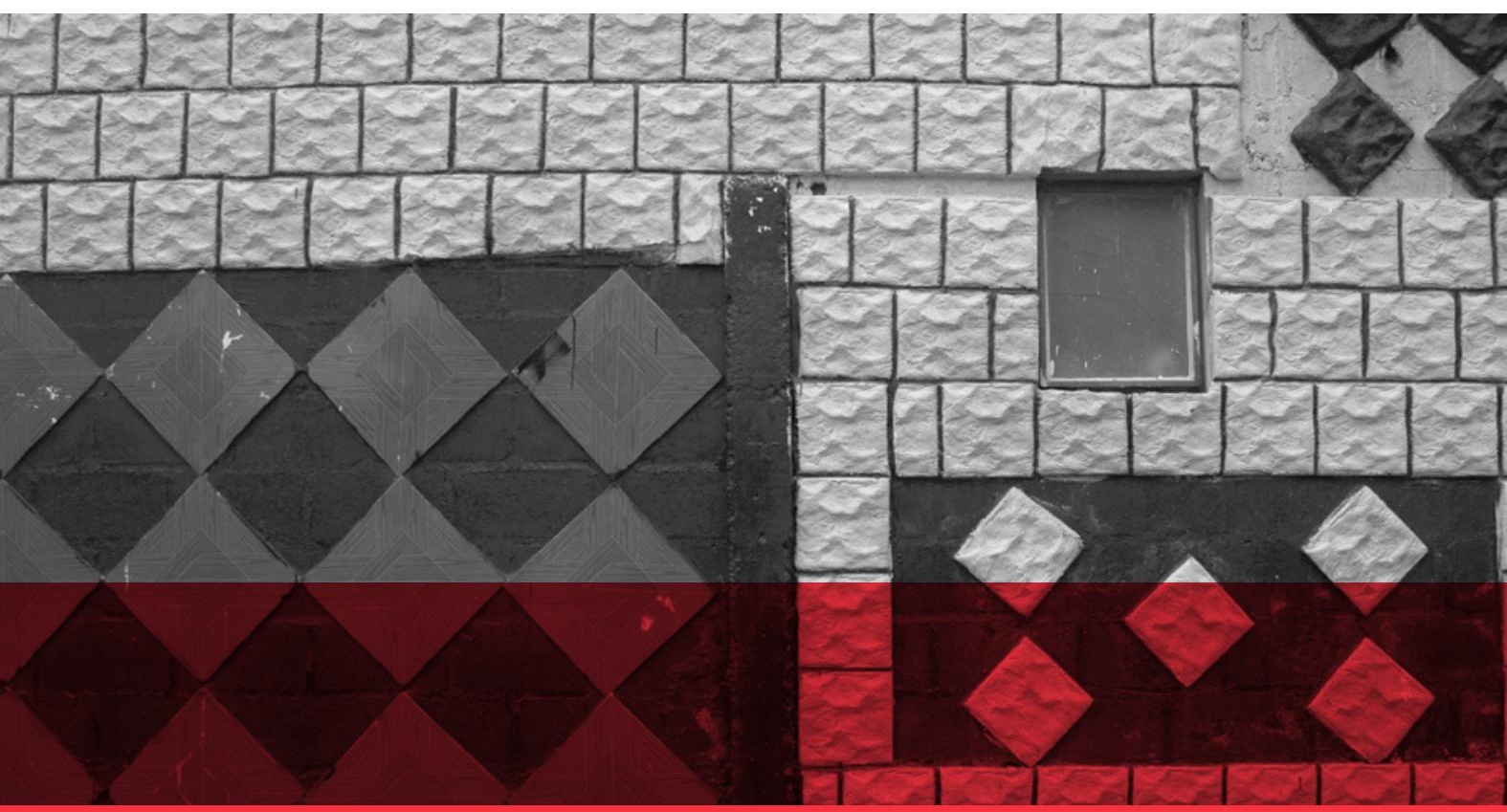

Hoje em dia, ao percorrer a Mafalala o visitante depara-se com a precariedade e degradação em que se encontra a maioria do espaço urbano e habitacional. Mas, com um olhar mais atento, vai-se apercebendo da existência de uma enorme riqueza sociocultural a cada virar de esquina. À medida que se penetra nas estreitas e labirínticas vielas, definidas pelos perímetros parcelares já descritos, e nos largos que as pontuam, vai-se sentindo o espírito do local formado por mais de um século de história e encontros de culturas. A diversidade sociocultural daí resultante encontra-se materializada em muitos pormenores que distinguem a Mafalala de outros espaços (sub)urbanos da cidade. 
No bairro coexistem e, em muitos casos, fundem-se comunidades de origem essencialmente africana, mas também asiática e europeia, com culturas diversas, que se miscigenam sem perderem uma identidade própria, num espaço intercultural em constante mutação e recriação. É este mosaico sociocultural que impregna os sentidos de quem visita aquele espaço urbano.

Neste espaço é visível uma enorme diversidade de detalhes construtivos de diferentes proveniências e influências. Desde as habitações em caniço, passando pelas de madeira e zinco, até às convencionais em alvenaria, ou mesmo outras que fundem estes três tipos com outros materiais mais recentes. Estas materialidades construtivas fundem-se numa rica paleta de cores, padrões e texturas, fazendo lembrar as capulanas tão presentes no bairro. Não menos interessantes, em termos visuais, são os anúncios pintados à mão que decoram paramentos e intensificam o espectro cromático e gráfico das ruas, a que se juntam os aromas e sabores de uma variada gastronomia. A experiência sensorial intensifica-se com o burburinho contínuo, ora do pregão dos comerciantes de rua que vendem desde deliciosas iguarias (samoosas, badjias, maçarocas assadas ou mathapas) às novidades da moda nas calamidades ${ }^{19}$; ora do contemporâneo ritmo do pandza (fusão de marrabenta, ragga e hip hop), das danças tradicionais, (como o tufo da llha de Moçambique), e ainda de outros estilos musicais criados, tocados e dançados em tempos idos (como é o caso da marrabenta de Fanny Mpfumu).

Mas percorrer a Mafalala não se reduz a uma mera experiência sensorial. As ruas e casas estão imbuídas de histórias, em particular da história dos moçambicanos, da história da Luta de Libertação e de alguns dos seus protagonistas. O bairro foi palco da resistência (sub)urbana ao colonialismo, no tempo em que se sonhava com o dia em que a liberdade reinasse naquelas ruas, naquele bairro, 


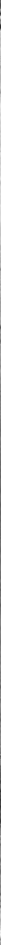

Uma das entradas do bairro, Setembro de 1974.

naquela cidade, naquele país. O sonho viria a materializar-se quando ecoou pelo bairro a senha "o galo amanheceu", que despoletou a derradeira revolução dos habitantes suburbanos contra as hostes reacionárias que pretendiam reverter o processo de independência de Moçambique.

\section{Os fatores de agregação}

À semelhança dos outros subúrbios, também os habitantes da Mafalala estiveram sujeitos a um sistema informal de pagamento de rendas aos proprietários dos terrenos onde se queriam fixar. Tendo como base estratégias de sobrevivência e solidariedade social comuns a outros tipos de migrações em África, estes povos agruparam-se predominantemente por entidade patronal, profissão, locador, local de origem, relações familiares, religião, cantina, entre outros fatores que se mantiveram até ao final do século XX (Silva, 2000).

Normalmente eram os homens que vinham primeiro para a cidade em busca de melhores condições de vida. Se não conhecessem ninguém tentavam arranjar emprego e fixar-se numa habitação precária o mais próximo possível do trabalho, pagando uma renda ao locador 
do terreno que, em alguns casos, era do próprio patrão. Quando as condições estabilizavam chamavam os familiares ou conterrâneos para se juntarem a eles (Rita-Ferreira, 1968: 244). Os recém-chegados tendiam a aglomerar-se dentro do perímetro da parcela do mesmo locador, a quem também começavam a pagar renda, muitas vezes de forma indireta, isto é, pagavam aos residentes mais antigos que, por sua vez, iam pagar ao locador. Desta forma, cada parcela suburbana funcionava como uma célula de acolhimento cujo núcleo se ia preenchendo predominantemente com uma comunidade de determinada origem, muitas vezes por ligações familiares a clãs ou religiosas.

Este último fator também foi preponderante na agregação populacional nos subúrbios. O vínculo a determinada religião ou variante da mesma, gerava polos de atração e agregação entre as populações migrantes. Neste aspeto, a presença das igrejas protestantes, nos territórios circundantes da baía, foi muito forte desde o último quartel do século XIX, influenciada pelas colónias anglo-boers do hinterland. Tinham, em geral, uma postura mais inclusiva e de proximidade para com os povos do sul do rio Save, o que fomentou a confiança de muitos deles e a desconfiança da administração portuguesa dominada pela igreja
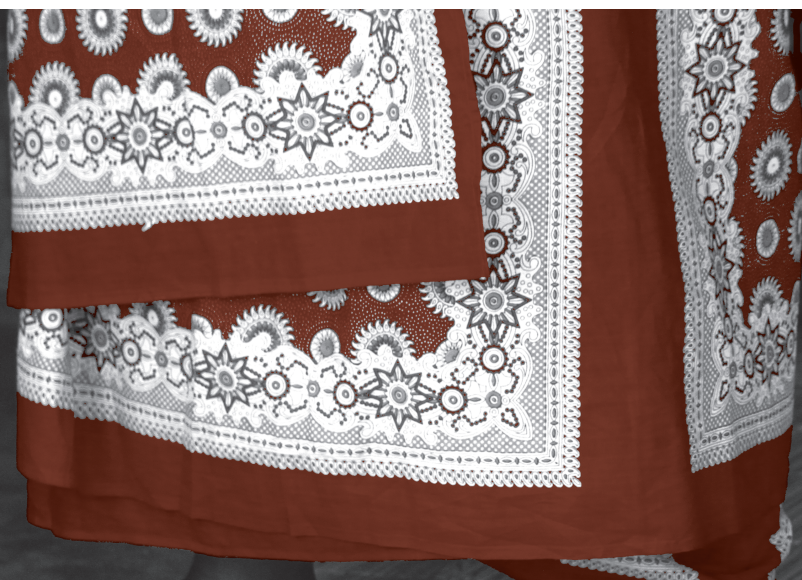
católica (Dores, 2014: 138-183).

O raio de influência destas missões/igrejas protestantes alargava-se a outros espaços suburbanos.

Na Mafalala, a predominância de povos swahílis, em especial da costa oriental de África e ilhas adjacentes $^{20}$, e a proximidade com os mouros ${ }^{21}$ do Alto Maé, fazia com que a religião islâmica tivesse uma maior influência e presença local, o que, em termos socioculturais, diferenciava a Mafalala dos restantes subúrbios. Mas a aceitação destas culturas de matriz swahíli, no panorama sociocultural dos subúrbios da cidade na viragem do século, nem sempre foi bem aceite ${ }^{22}$, como se aponta em vários artigos d’O Africano da época, que tecem duras críticas à comunidade macua, em particular, ao ruído e estranheza de certos rituais ${ }^{23}$. $\mathrm{Na}$ capital de Moçambique a resistência inicial à cultura macua vinha de diversos quadrantes. Da

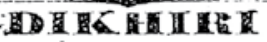

(Barulho infernal...)

Chamamos a altençäo do sr. admi. nistrador do Concelho para o barulho que, durante a noite e aos domingos durante a tarde inteira, se ficz n'uina casa da Munhuaua.

Diz-se qua aquillo é uma resa musulmana, para propaganda da religiăo Mahometona.

0 certo é que na tal casa, um cubiculo sem ar, e sem luz, juntam-se dezenas de macuas machos, ferneas e creanças, a borrarem desalmadamente "ha, $h a, h a, h(t)$, isto durante horas, com as j.uclias e portas fechadas,

Quando abrem urna porta sahem por ella uns diabos a destillar suor, creanças guasi asfixiadas, correndo

n'um tumulto ans barris d'agua, onde bebem, suffregos: umá furt: golada d'aguil cristilina!

- Aquullo não é religião, ñão é nada é um pretexto para a vidiula ociosa... com malherio á moxtura; e é ainda a lai coist de desviallo indigena da civilsaceno portngur\%, incutinde. The no animo o odto as christios...

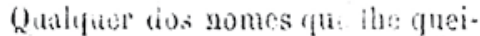
rain diar, pureni, o certo e positivo $\therefore$ que nit) deve continuar porrase uni barulho d'ensurdecer.

Contamos com as providereiss d: adınivistraçĩo para nos livera de tal calamidade.

O Africano, 22.05.1909. parte dos colonizados, pelo choque cultural com os povos do sul do rio Save. Do lado dos colonizadores, pela hegemonia cristã (católica e protestante) e pelo discurso económico protecionista anti-indiano, em particular anti-muçulmano, que predominava nas hostes nacionalistas do colonialismo europeu da África Oriental.

Este fator veio reforçar a coesão das comunidades africanas islamizadas da Mafalala que, para protegerem e preservarem a sua cultura, tiveram uma forte vertente associativa. Utilizando as redes das zonas de origem onde se associavam em confrarias ou irmandades "de caráter reservado 
e absoluta predominância masculina" e dedicadas não só às práticas religiosas como também a "associações mutualistas" que conferiam à comunidade uma identidade própria (Rita-Ferreira, 1968: 457). Refira-se que na Mafalala existiam quatro confrarias, três da ordem Shadhuliyya ${ }^{24}$ e uma da Qadiriyya ${ }^{25}$ (Carvalho, 1988: 61-65; Lemos, 1988: 52-53). Além da componente religiosa, a vertente mutualista de proteção social da comunidade pertencente a cada confraria, pesava na escolha do local de fixação dos migrantes conterrâneos ou confrades islâmicos que se estabeleciam no bairro, sendo um importante fator de agregação.

Algo semelhante acontecia na relação das comunidades suburbanas com as cantinas. Este tipo de entreposto comercial foi uma das vertentes do capitalismo colonial que mais interferiu no quotidiano

Chegada de novos membros à Mesquita Baraza, 2013.

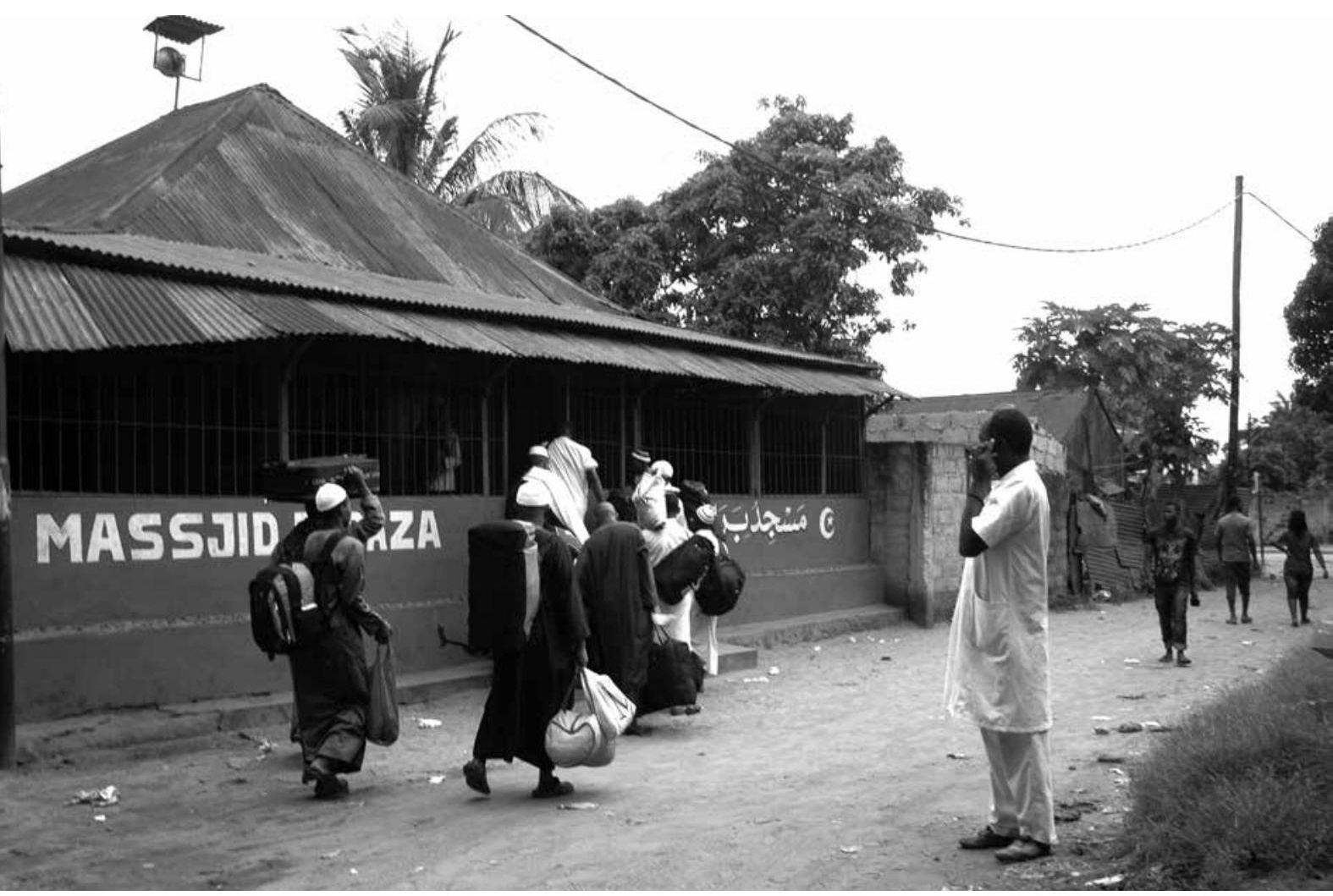




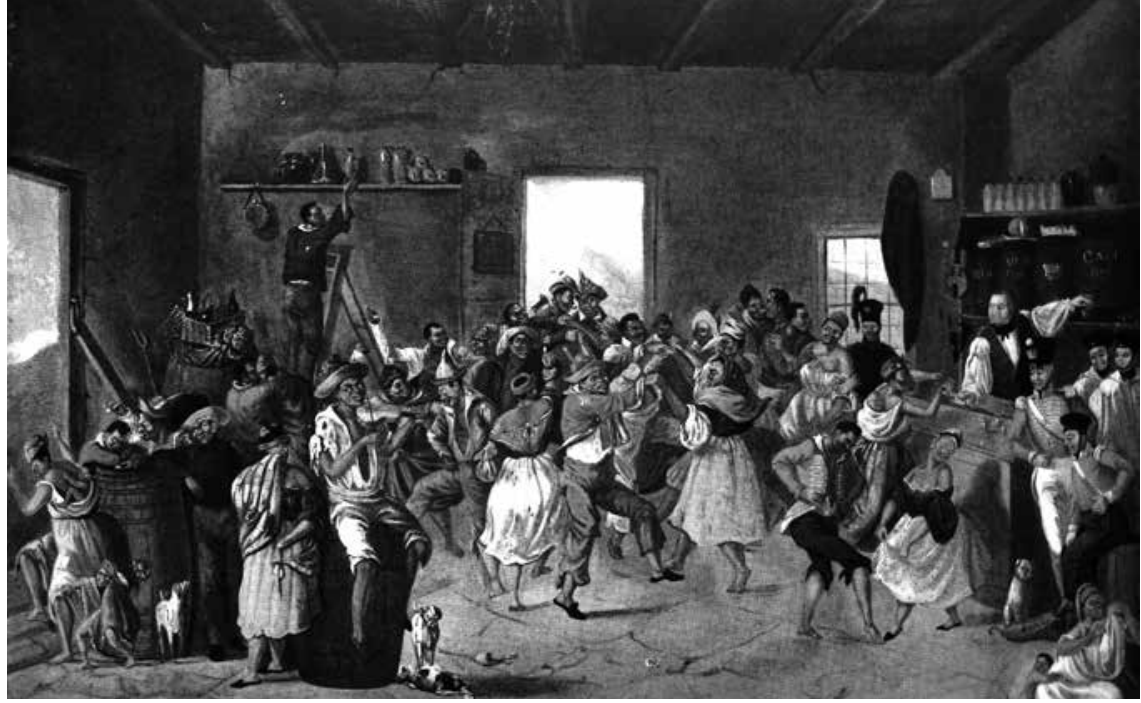

Canteen Scene Potter's Inn, Grahamstown (África do Sul), 1850. Pintura de Frederick Timpson I'Ons.

dos colonizados, não só no meio rural, mas também, e com maior incidência, nos tecidos suburbanos. A degradação da vida rural da maioria dos africanos e a sua consequente urbanização, tornou-os mais dependentes desta forma de comércio. O rápido desenvolvimento económico no final do século XX gerou um proletariado africano, que, apesar dos magros salários, rapidamente se embrenhou no consumismo capitalista da economia colonial. Os povos de origem indiana, em particular os ligados ao sistema colonial britânico, foram dos primeiros a explorar o filão comercial das cantinas, em continuidade com a sua tradição secular de entrepostos comerciais no hinterland da costa oriental africana. Com o arranque da economia colonial do século XIX, as cantinas vão preencher informalmente o hiato no sistema de fornecimento de bens aos povos nativos. Começaram por se estabelecer junto das minas e povoações rurais de onde provinha a mão de obra africana para o Transvaal, aliciando-a com uma miríade de produtos que ia desde os mais essenciais, como os alimentos, até aos mais supérfluos e nefastos, como o álcool e a prostituição (Harries, 1994: 101-105).

Mais uma vez a influência das colónias anglo-boers do hinterland vai refletir-se no quotidiano da capital de Moçambique, onde o mote do negócio das cantinas seguiu o das congéneres sul-africanas. No auge do já mencionado discurso higienista do início do século $X X$, as autoridades coloniais portuguesas proibiram definitivamente a existência de cantinas intra circunvalação, em especial no Alto Maé, cerceando, ainda mais, os movimentos dos africanos para as zonas suburbanas (Sopa, 2014: 44-46). 


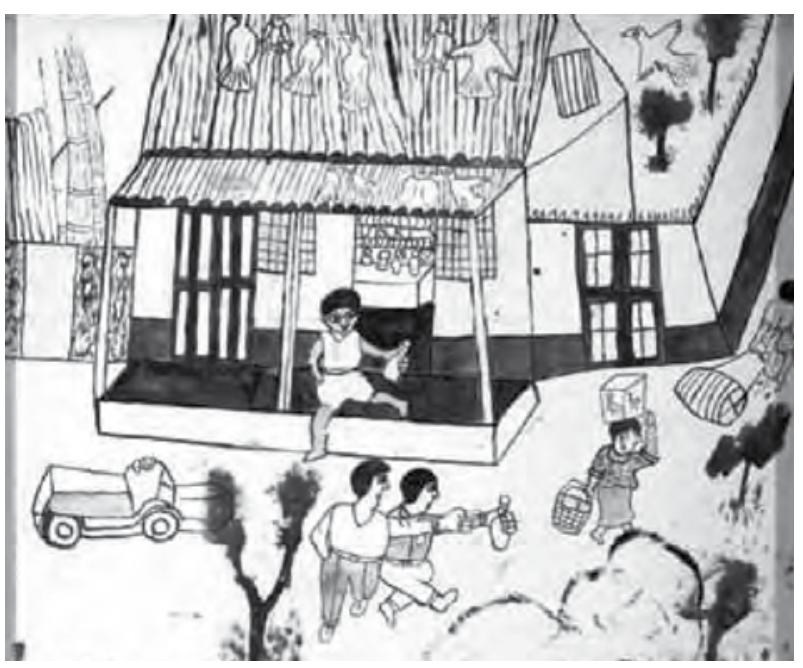

Cantina dos subúrbios

de Lourenço Marques,

1962. Desenho de

Augusto Naftal.

Com o tempo as cantinas foram acumulando mais valências. Num habitat densamente povoado e degradado, onde faltava quase tudo, desde os bens alimentares às infraestruturas básicas, como água potável e saneamento, as cantinas tornaram-se, cada vez mais, imprescindíveis à sobrevivência dos habitantes suburbanos, como os da Mafalala. Conscientes desta dependência, os cantineiros tornaramse atores preponderantes na hierarquia colonial suburbana, mantendo uma relação ambígua e assimétrica com a clientela africana.

Cantina Mercearia Lourinhã nos subúrbios de Lourenço Marques, década de 1960.

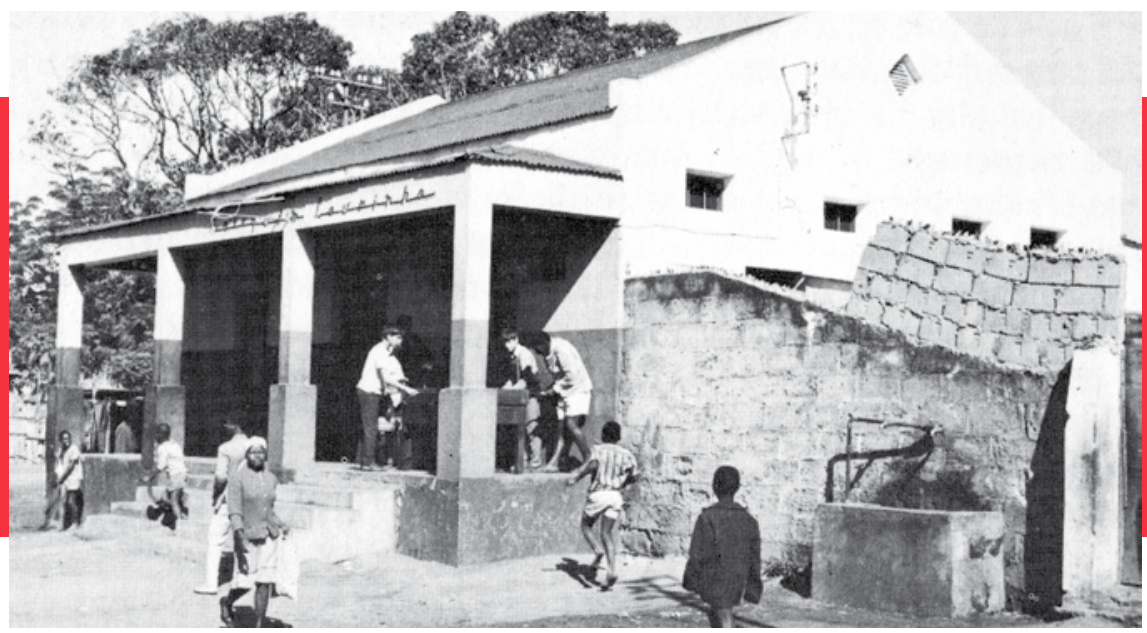


Esta, devido à precariedade laboral e económica a que estava exposta, era impelida a recorrer ao crédito informal que os cantineiros Ihe facultavam. Na linha do que já foi mencionado, um dos rituais iniciáticos dos migrantes africanos recémchegados aos subúrbios era irem ao cantineiro, onde os seus familiares ou conterrâneos já eram clientes/ credores. Aí abriam conta no livro com o aval dos familiares, ficando assim evidente a importância das cantinas na vida da população, a ponto de determinarem a fixação destes migrantes em parcelas nas suas imediações.

Até à independência, as cantinas foram um tema recorrente na literatura moçambicana, sendo normalmente descritas como espaços assimétricos de violência social ${ }^{26}$, mas foram também locais de fusão intercultural onde se difundiam, entre outros, novos estilos musicais como a marrabenta (Laranjeira, 2014; Sopa, 2014).

Além destes fatores de fixação e agregação das comunidades africanas nos subúrbios houve outros como a proximidade dos poucos fontenários existentes, cuja escassez favoreceu uma lucrativa venda de água potável por parte de alguns cantineiros (Câmara Municipal de Lourenço Marques, 1953: 51; Pereira, 1971: 34).

Do que já foi referido sobre a estrutura urbana da Mafalala, há a reter a forma como os seus habitantes se organizaram, empiricamente, em espaços que não foram preparados para os receber. Reagindo às condicionantes acima descritas, em especial às coloniais, foram construindo uma outra cidade, com dinâmicas próprias e geradoras de novas relações de onde provém parte das características socioculturais moçambicanas. 


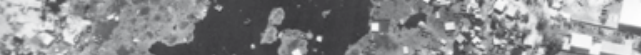
60. 3. atsotions

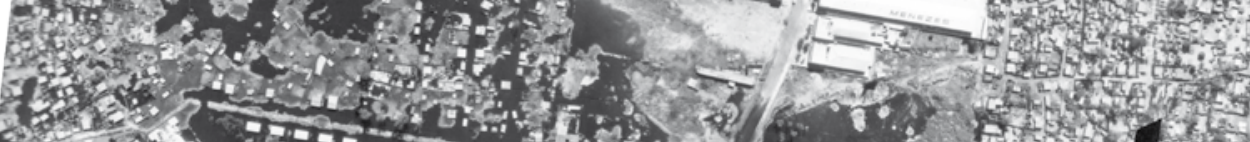

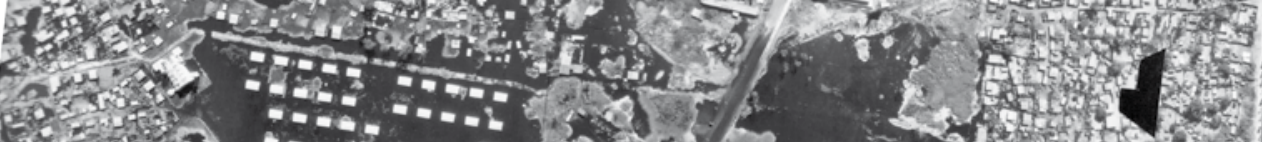

(ex) 25.

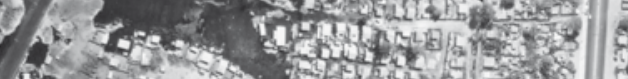

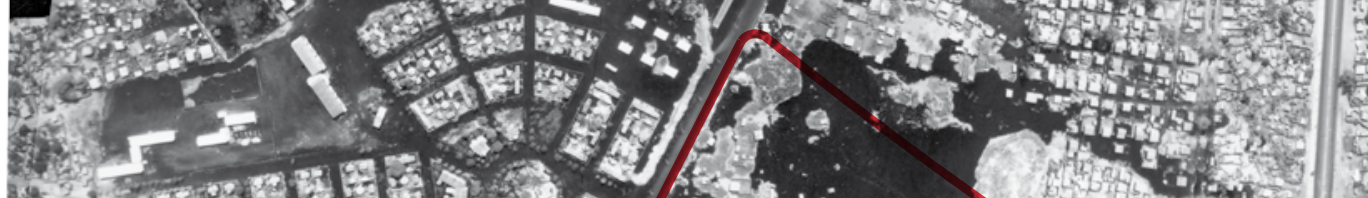
1. co tin 2

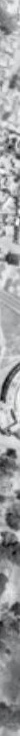

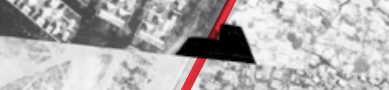

,

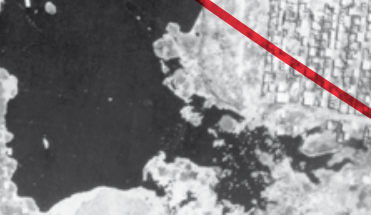

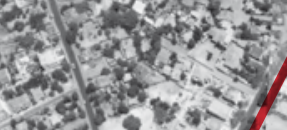
ary

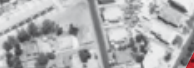

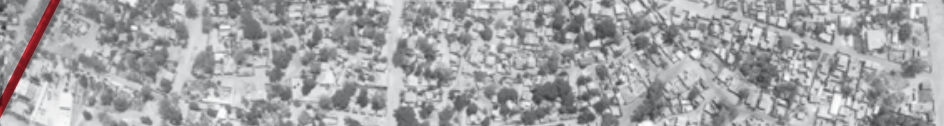
Hes
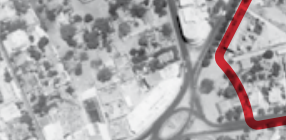

(3)

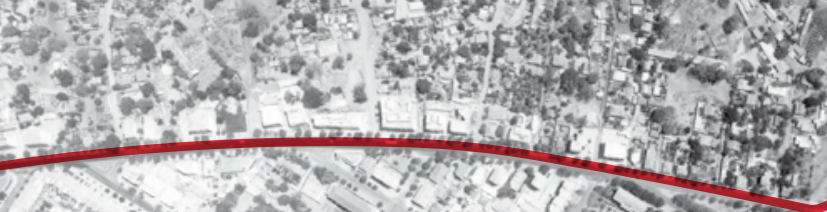

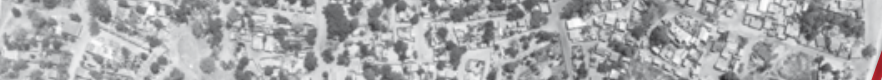

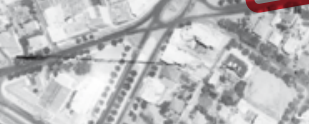

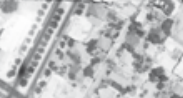

xito 


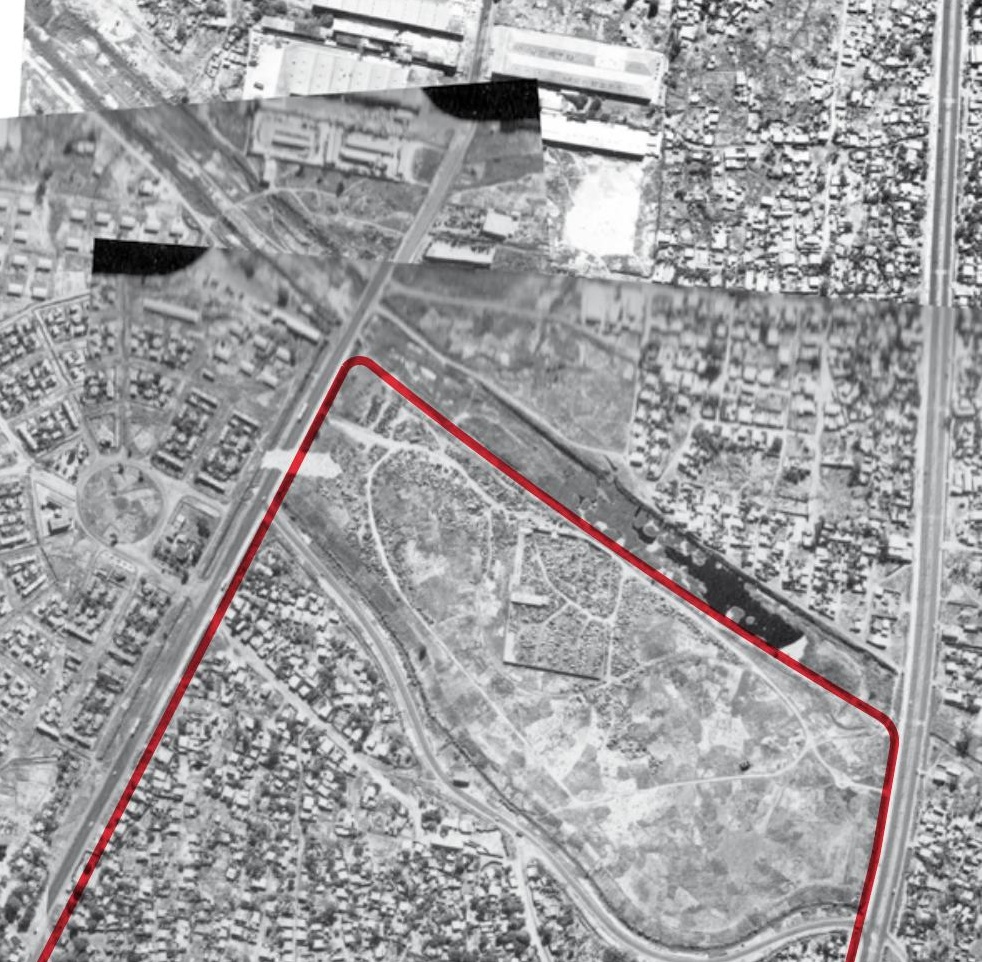

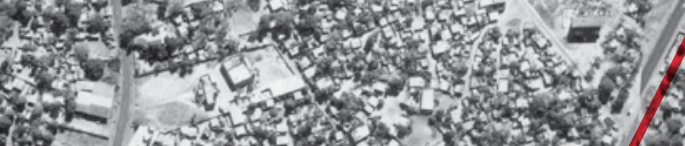

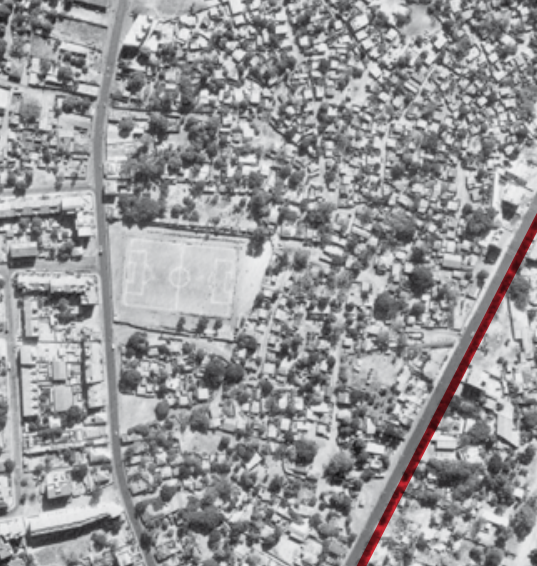

Sor.

L.

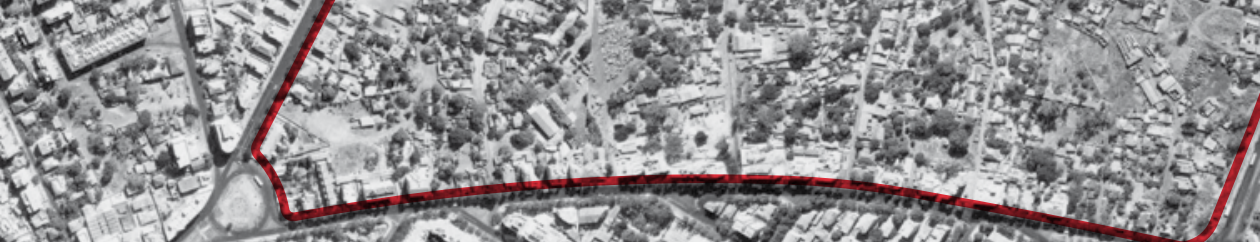

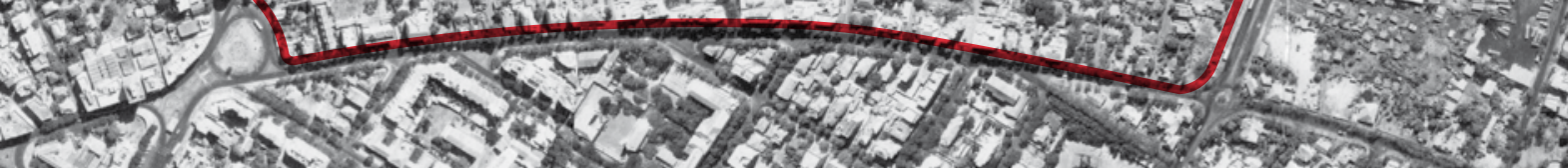

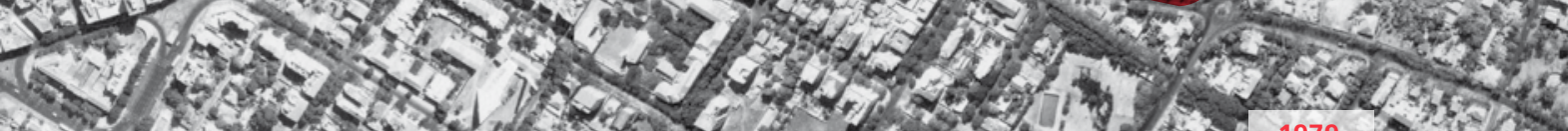

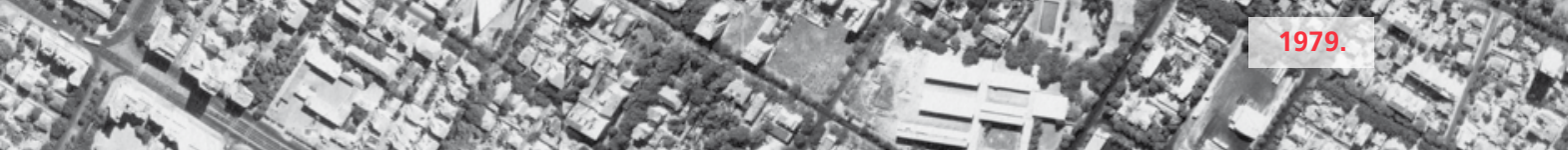

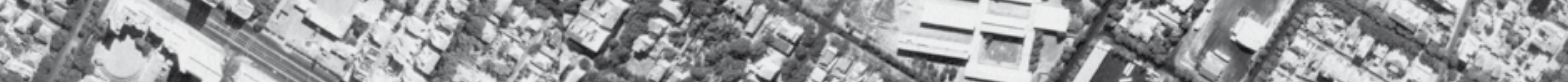

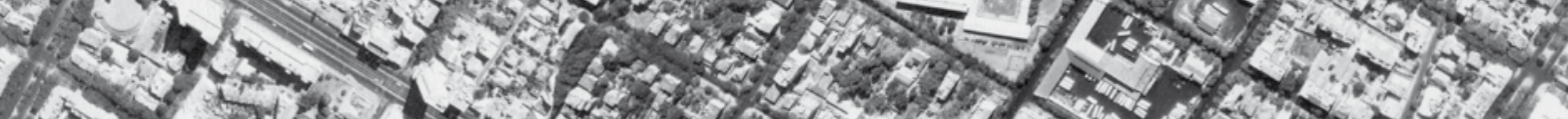
20
5 


\section{A arquitetura}

A diversidade sociocultural da Mafalala refletiu-se na heterogeneidade das habitações que desenharam o seu espaço urbano, determinado por diferentes métodos e materiais construtivos que caracterizaram a arquitetura local. À semelhança do que acontecia noutros subúrbios, os habitantes da Mafalala eram permeáveis e inclusivos à aplicação de novas técnicas e materiais na construção das suas habitações. Estas influências arquitetónicas provinham de diferentes quadrantes culturais da sociedade colonial da época, resultando em exemplares arquitetónicos híbridos, muitas vezes heteróclitos, que foram pontuando o bairro.

Devido à precariedade já descrita, na fase de fixação e adaptação ao ambiente (sub)urbano, muitos dos métodos e materiais construtivos eram utilizados de forma a assegurar um abrigo básico e provisório para o indivíduo e, se fosse o caso, outras pessoas próximas (família, amigos, conterrâneos, etc.). Em geral, o refúgio inicial não era planificado, mas sim edificado consoante as condicionantes económicas e locais o que enfatizou o carácter fragmentado, quase aleatório, do tecido edificado dos subúrbios ${ }^{27}$, que contrastava com a planificada e ortogonal xilunguíne. Cada novo habitante suburbano construía provisoriamente como e onde podia, segundo as técnicas construtivas das zonas de proveniência, recorrendo muitas vezes à ajuda da muti ${ }^{28}$, ou à comunidade mais próxima, normalmente da mesma zona de origem. Conforme as necessidades

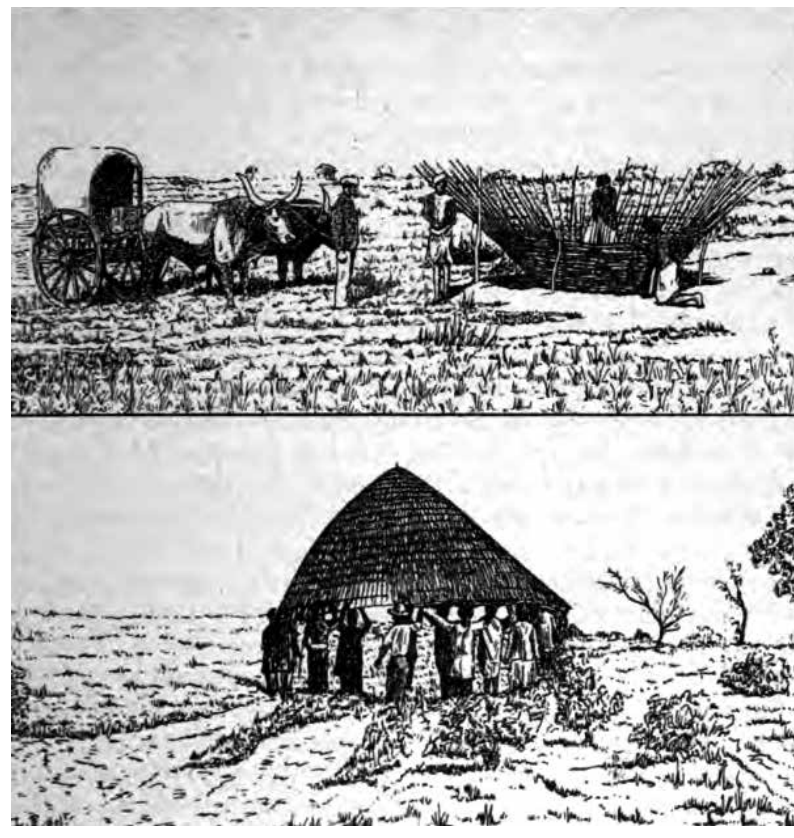

Execução da cobertura cónica da casa

tradicional cilíndrica dos Mpfumu. 
e as condições económicas iam melhorando a habitação, tanto na qualidade dos materiais como na ampliação do espaço.

\section{Os métodos e materiais construtivos}

\section{0 pau a pique}

Este método construtivo é um dos mais ancestrais e comuns na cultura bantu da África subsaariana. As principais razões da sua ampla difusão são: a facilidade em angariar os materiais, a forma de os transformar num abrigo e as boas performances contra as condições climatéricas locais, caraterizadas pelo calor e chuva intensa. Salvo raras exceções, como as construções em pedra do Grande Zimbabwe, o material predominante era de origem vegetal, podendo os paramentos ser rebocados (maticados) com solos argilosos. Se os métodos e materiais construtivos são semelhantes, já as formas podem ser diversas, predominando as habitações de planta circular e cobertura cónica ou semiesférica, comum entre os povos a sul do rio Save, e as de planta poligonal e cobertura de duas ou quatro águas, difundidas pelas comunidades swahílis a norte do mesmo rio (Carrilho; Lage; Bruschi, 2005: 5-7).

O primeiro modelo foi o mais utilizado nos territórios circundantes da baía até ao século XX, em particular pelos tsongas. Tradicionalmente os seus aglomerados populacionais restringiam-se à família alargada, onde as habitações eram organizadas em redor do recinto do gado (kraal). Em termos técnicos, o $/$ wango $^{29}$ era o elemento mais complexo e exigente de executar, sendo construído junto de zonas de fácil acesso à matéria-prima. Aí se montava a estrutura num cone invertido com 45 graus de inclinação, previamente escavado no solo, que funcionava como molde de diâmetro e profundidade variável conforme o pretendido. Depois de montada, a estrutura de madeira era transportada para o local onde iria ser edificada a habitação. Só mais tarde é que o paramento cilíndrico passou a ser construído em caniço estruturado com madeira. Esta última era então aplicada e vedada com o recurso a folhas secas de determinadas plantas, conhecidas localmente por luh/wa (Junod, 1912: 87-95). 
Detalhe do Mapa (holandês) com as feitorias na Baía de Lourenço Marques, 1726. "a" indica a feitoria holandesa, "b" a atual Baixa de Maputo; "c" a área do Maxaquene, "d" a Ponta Vermelha, "e" a Polana, "f" o Alto do Mahé, "g" Katembe, "h" a fortaleza projetada, "i" Kraal com casas de planta cilíndrica dos nativos, "j" área agrícola projetada.

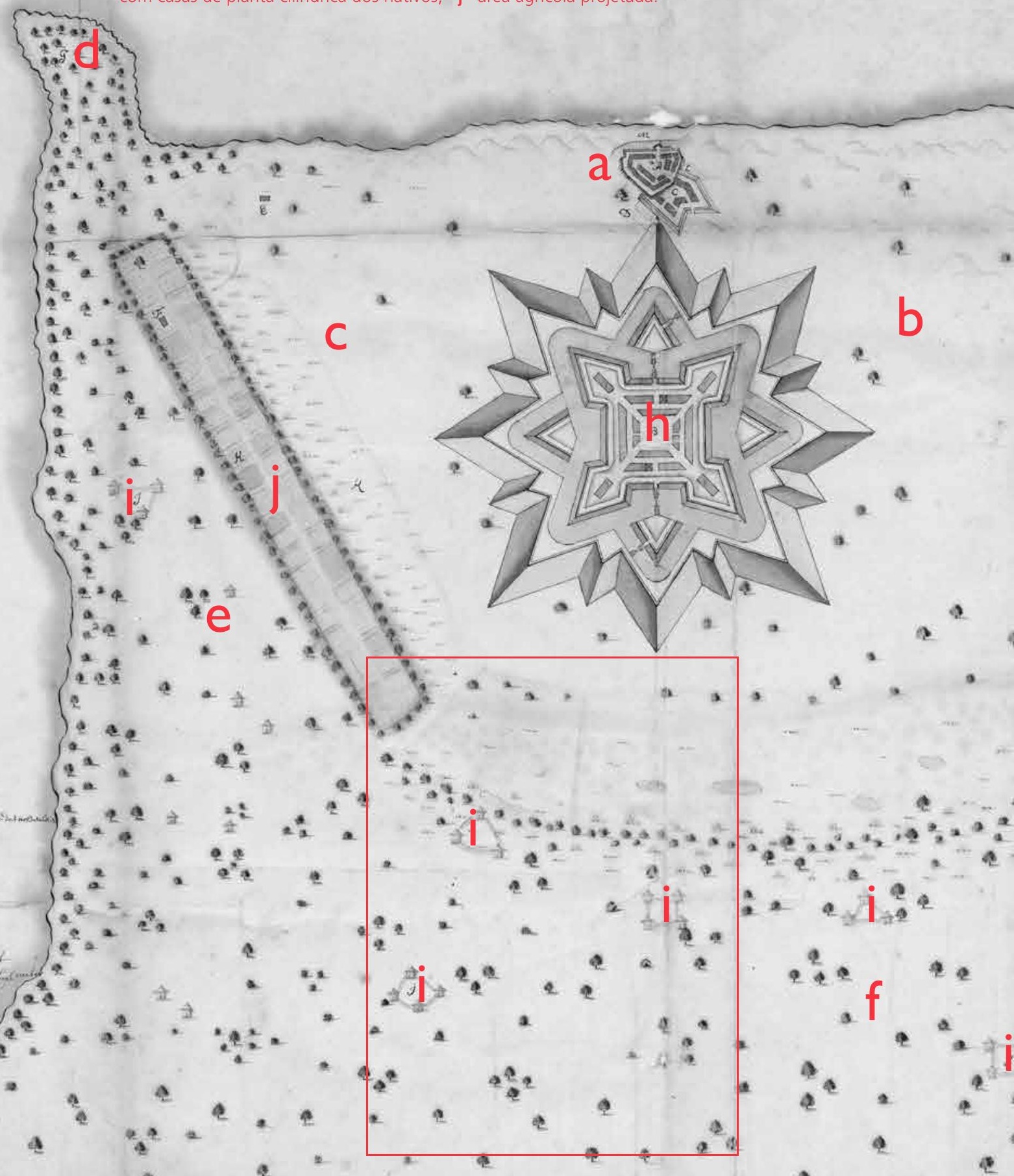




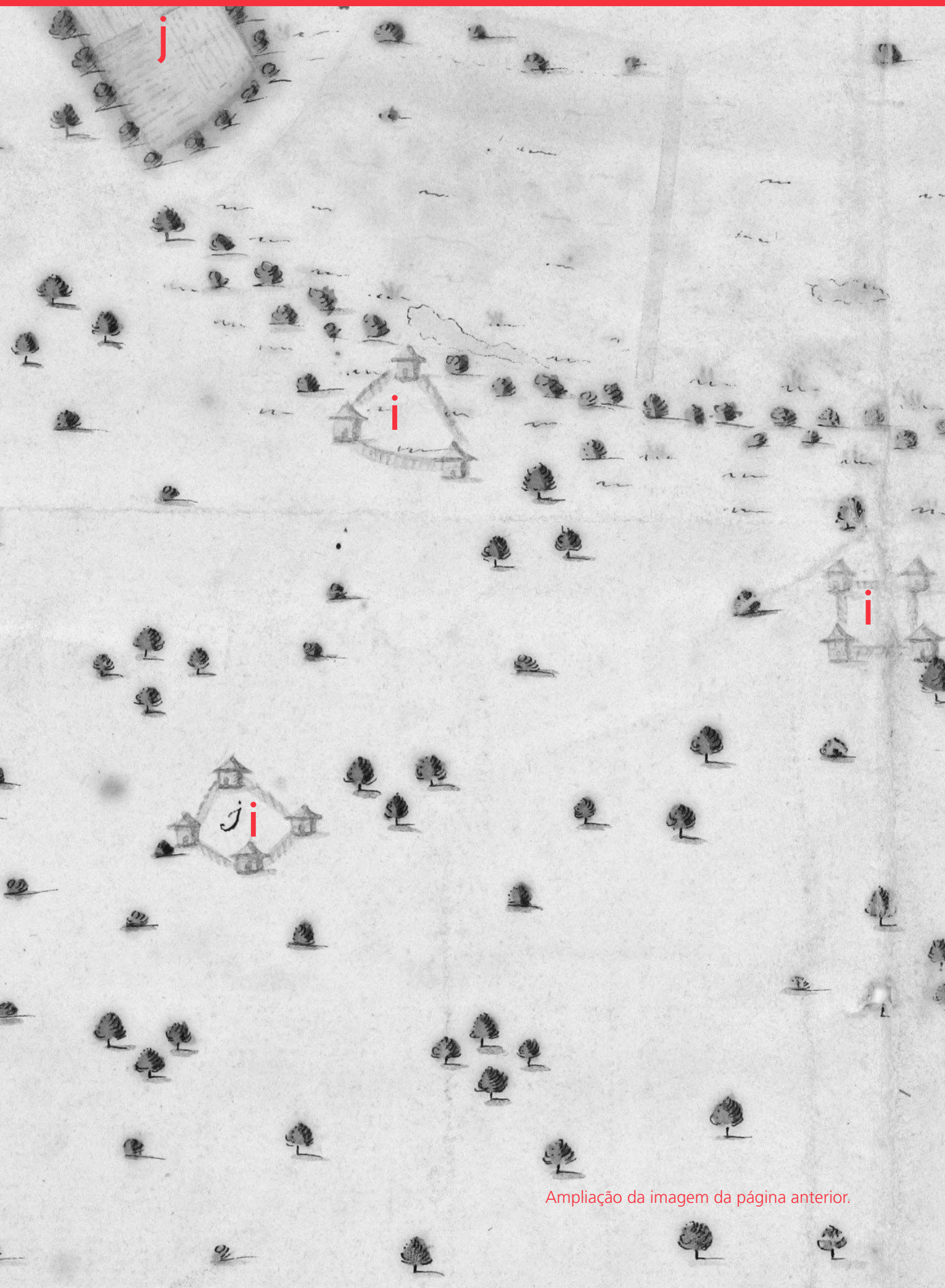


Devido à complexidade de execução a estrutura da cobertura era muitas vezes reutilizada, quando os proprietários pretendiam mudar para outro local.

No mapa holandês que representa a baía no primeiro quartel do século XVIII, é bem visível o predomínio do modelo cilíndrico na povoação Mpfumu no planalto onde, mais tarde, se viria a implantar a cidade alta e os subúrbios ${ }^{30}$. No início do século XIX, os pioneiros

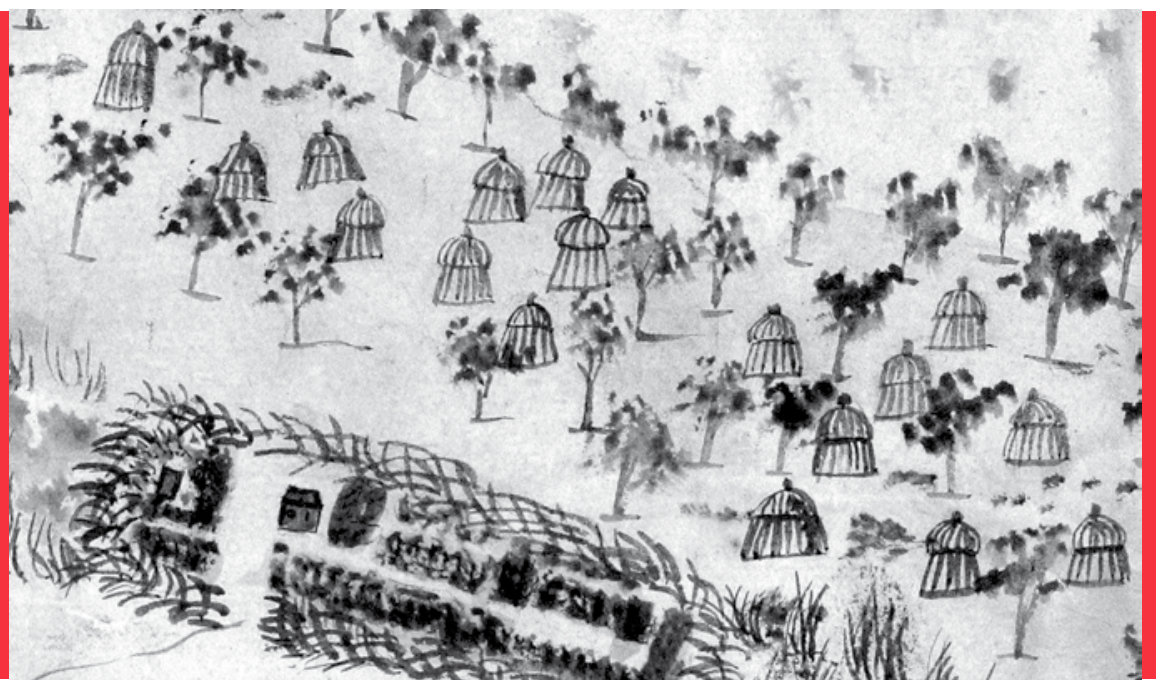

Detalhe de Mapa (holandês) com representação das casas cilíndricas da população nativa, 1721

portugueses que se estabeleceram em redor do presídio ainda usaram este modelo para as suas habitações, algo que se manteve até ao final da década de [18]60. Mas com o passar do tempo este método construtivo foi sofrendo algumas alterações formais e materiais, introduzidas pelos estrangeiros que iam chegando cada vez em maior número. Eram não só europeus, como também indianos católicos (goeses), baneanes hindus e muçulmanos do Guzarate, estes últimos com fortes ligações à llha de Moçambique onde eram considerados exímios construtores de habitações bem-adaptadas aos climas tropicais. (Lima, 1968: 12, 16, 20, 29). Aí, já há muito que as casas dos povos locais eram projetadas com base poligonal e coberturas de duas ou quatro águas, cuja influência é frequentemente referida como proveniente da cultura construtiva islâmica do mar Arábico, 
tanto dos povos do Médio Oriente, como dos da costa malabar indiana (Carrilho, 2005: 30-35).

Com a mudança da capital da Ilha de Moçambique para Lourenço Marques, a habitação swahíli difundiu-se pelos subúrbios da cidade, em particular pela comunidade macua que vivia nas terras altas do régulo "Maié ou Mahea", mais tarde conhecidas por Alto

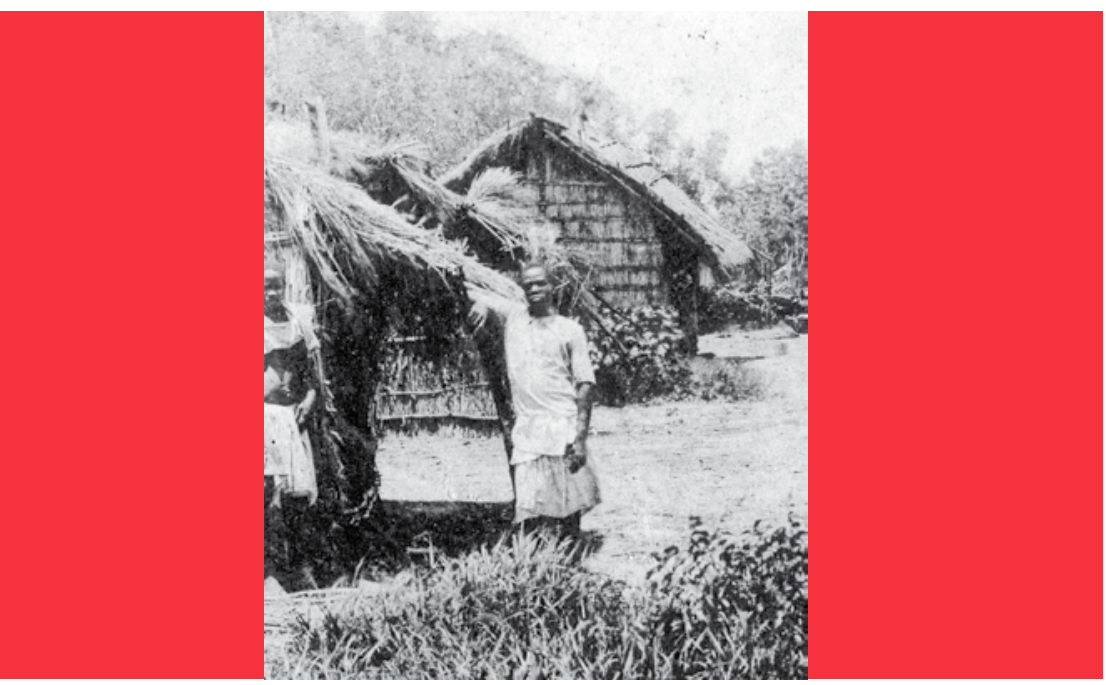

Detalhe do postal Souvenir de Lourenço Marques:

The Native Location, com habitação de planta retangular, 1900.

[do] Maé (Noronha, 1895: 59). Os materiais utilizados pelo modelo poligonal eram idênticos aos do circular, divergindo no método construtivo da estrutura da cobertura e na organização do espaço interior. A geometria do modelo swahíli veio a demonstrar-se mais versátil no meio (sub)urbano, tanto para possíveis ampliações a partir do mesmo volume, tão importantes para as famílias alargadas que viviam nos exíguos espaços suburbanos, como pela facilidade em se adaptar a outros materiais construtivos. Contrariamente, nas casas de planta cilíndrica era mais difícil executar os paramentos em alvenaria ou a cobertura cónica em chapa de zinco, o que as tornava menos adaptáveis às mudanças e exigências habitacionais das populações suburbanas. 


\section{A madeira e o zinco}

A relação geográfica da capital moçambicana com as colónias anglo-boers do hinterland foi preponderante para a disseminação dos edifícios pré-fabricados em chapas metálicas onduladas nos métodos construtivos locais. A introdução e disseminação deste material resulta, essencialmente, do desenvolvimento do corrugated iron, na Europa, especificamente na Inglaterra, desde o início do século XIX. A indústria inglesa foi mais eficaz não só no processo produtivo como também na comercialização/ disseminação do produto. Este fenómeno está intimamente relacionado com a expansão colonial europeia da época. No caso inglês, os catálogos de kits pré-fabricados de madeira e zinco propagaram-se rapidamente pelas possessões sob sua influência direta ou indireta. Facilmente quantificados, transportados, armazenados, montados, desmontados e reutilizados, os kits foram fundamentais para a implantação das colónias britânicas (Warr, 2001: 1-2), em particular as que mais apostavam nas explorações mineiras e nas linhas férreas, como era o caso da África Austral.

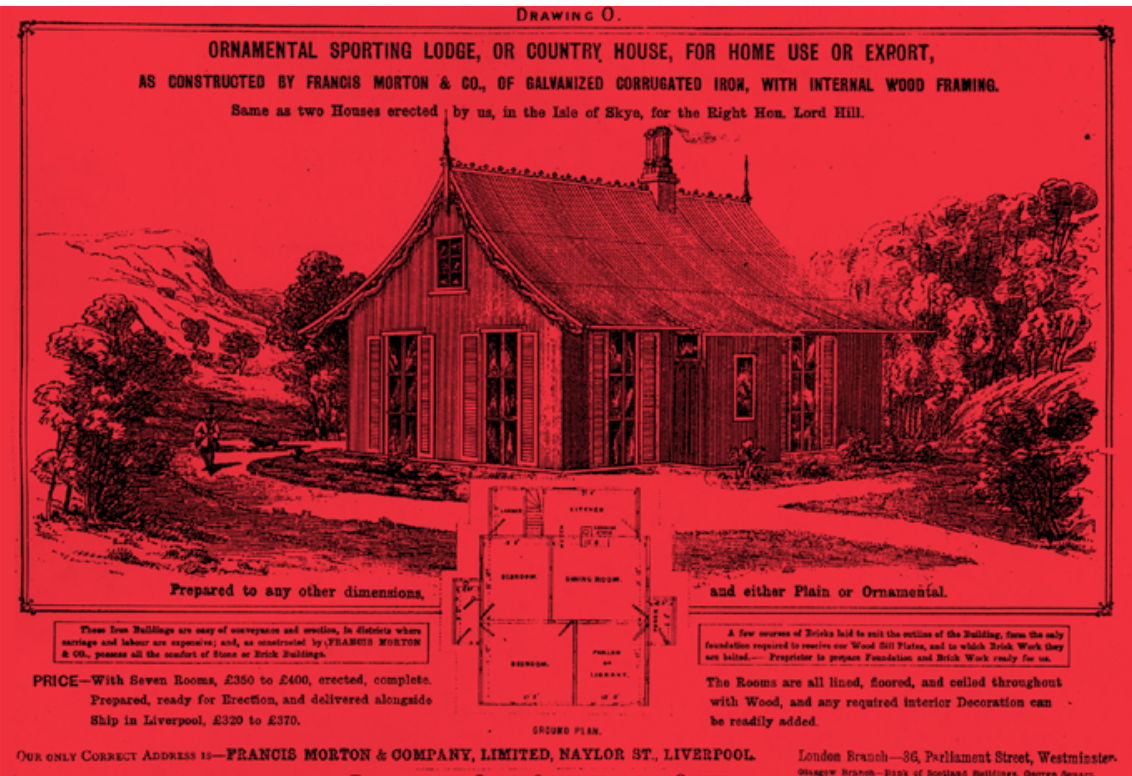


Nas primeiras, que começaram a proliferar no Transvaal no último quartel do século $X X$, a incerteza quanto à qualidade e quantidade do minério fazia com que, não raras vezes, os compounds onde se alojavam as grandes massas laborais indígenas tivessem de ser desmontados e montados em outros locais de exploração, o que fazia dos kits de madeira e zinco peças fundamentais nessa logística. De forma semelhante a implementação da rede férrea iria necessitar destes kits para os estaleiros temporários ao longo dos trajetos, além de também serem amplamente utilizados em novas estações e povoados.

O facto destas colónias do hinterland dependerem do PCFLM para importar e exportar os seus produtos, fez com que aí se começassem a estabelecer muitas empresas de transitários e materiais de construção anglo-boers, possibilitando o comércio de chapas de ferro zincado e dos kits pré-fabricados (Lima, 1968: 36).

Desta forma, este material e método construtivo rapidamente se propagou pela capital de Moçambique, principalmente a partir da postura municipal de "aformoseamento geral das edificações e das

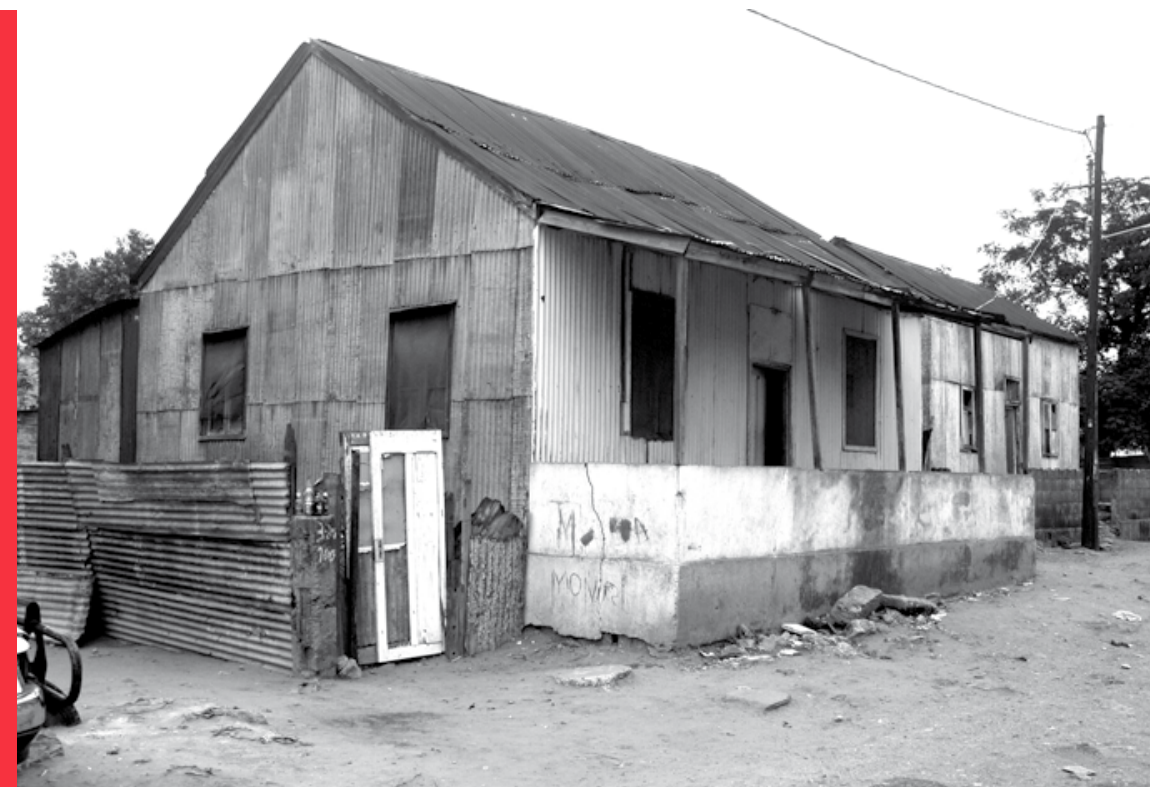

Casa de madeira e zinco, 2013. 


\section{A alvenaria de adobe, cimento e betão}

Até ao final do século XIX a construção de alvenaria em adobe foi pouco significativa no panorama arquitetónico da xilunguíne e ainda menos nos subúrbios.

Na mesma época identificaram-se nos arredores da baía zonas de recolha de matérias-primas para fazer construções e paramentos, de razoável qualidade, em alvenaria de pedra com recurso à cal e ao cimento. Mais uma vez, seria a influência britânica do hinterland, através das obras da via-férrea, a fomentar a implementação destas tecnologias construtivas na capital. Com estas introduziu-se, ainda numa fase muito experimental, os primeiros elementos em betão armado com recurso aos materiais da própria linha, como os carris metálicos e brita, que se misturavam com o cimento e a areia.

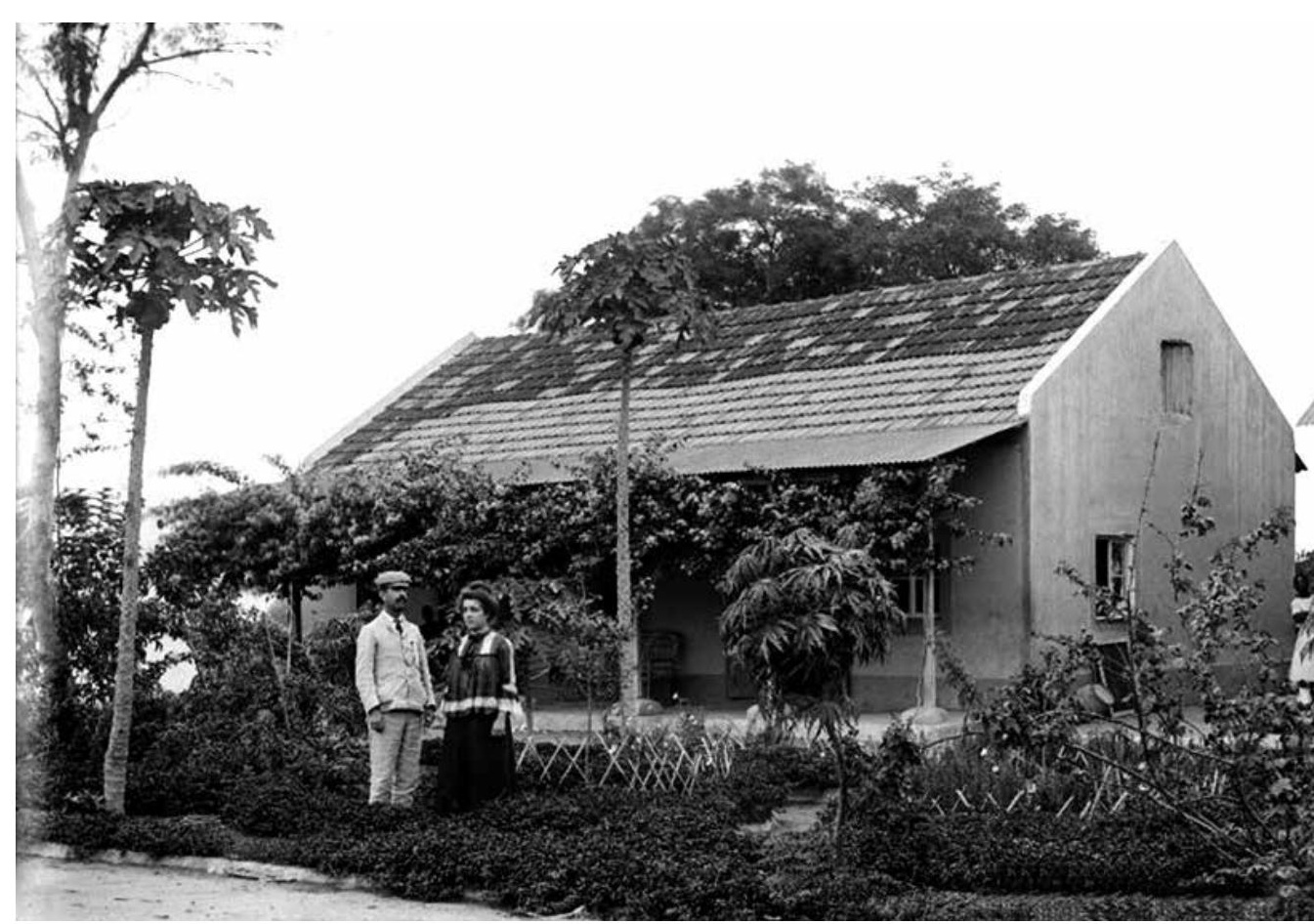

Casal europeu no exterior de uma casa de alvenaria com telha cerâmica tipo francês em

Lourenço Marques, início do século XX. 
O arranque do século foi uma época de avanços e ensaios nas tecnologias construtivas na cidade, sendo muitos os exemplos de edifícios onde se fundiram vários métodos e materiais. Este fenómeno verteu-se nos subúrbios traduzindo-se, especificamente no caso da Mafalala, numa intensificação da diversidade plástica da paisagem urbana.

A Implantação da República, em 1910, e a ideia de progresso a ela inerente, contribuíram para a ascensão do cimento e da cal em detrimento dos métodos construtivos descritos anteriormente. Tal como a madeira e zinco tinha sido utilizada como argumento civilizacional para denegrir, substituir e segregar as construções tradicionais bantus, o cimento e a cal produziram o mesmo efeito sobre as construções em madeira e zinco. Em 1910, o médico responsável pelos Serviços de Saúde, movido pelo sanitation syndrome da época, insurgiu-se contra as construções de madeira e zinco com argumentos higienistas, afirmando que já era tempo de a capital "perder o seu aspeto mesquinho de 'cidade de lata'"31, algo que se materializou dois anos depois, com uma postura municipal a proibir as licenças para esse tipo de construções dentro dos limites da xilunguíne.

Depois de um curto período onde o fulgor progressista republicano quis contrariar a especulação britânica do cimento Portland, recorrendo à cal dos territórios a sul da baía, este acabaria por prevalecer. No final da Primeira Guerra Mundial o licenciamento e construção na Matola recorreria à fábrica de capital e tecnologia inglesa, Mozambique Portland Cement. No Estado Novo, a retórica colonialista agudizar-se-ia e a fábrica seria nacionalizada, sendo posteriormente entregue à Empresa de Cimentos de Leiria, em 1944 (Lima, 1968: 65-69). Estava assim consumado o domínio hegemónico do cimento nos sistemas construtivos da xilunguíne que, a partir desta época, começou a ser conhecida como cidade de cimento. Esta reforçou a sua imagem de um espaço urbano e arquitetónico civilizado, em contraponto com o caniço, ou subúrbio, o que agudizou ainda mais a sua conotação primitiva aos olhos e nos discursos dos colonizadores. 


\section{A materialidade como identidade}

Uma semântica segregacionista, ligada aos métodos e materiais construtivos, foi-se incorporando na retórica e na hierarquia colonial, determinando o cimento e o betão como o nível mais elevado da civilização e o pau a pique, ou caniço, o mais baixo. Num estádio intermédio permaneceriam as construções de madeira e zinco, de conforto térmico muito inferior ao do caniço, mas que representava para os povos africanos urbanizados um estatuto mais elevado. Para as elites que emergiam dos subúrbios, no primeiro quartel do século XX, "substituir a palhota primitiva pela barraca de zinco [era] uma das manifestações de civilização" 32 (O Africano, 1915).

Este fascínio está relacionado e foi potenciando pela proximidade com as colónias anglo-boers para onde se dirigiam grandes fluxos migratórios dos mineiros ${ }^{33}$ rumo ao Transvaal. Os principais objetivos desses emigrantes era não só ganhar prestígio dentro da comunidade de proveniência, como também dinheiro para assegurar um bom lobolo (dote) para o casamento. Parte do imaginário de progresso que traziam das cidades mineiras do hinterland eram as casas de madeira e zinco que por lá proliferavam. Regressar das minas e construir uma habitação deste género, se possível nos subúrbios da capital, significava uma promoção social dentro da comunidade onde estavam inseridos. A ascensão do cimento e, mais tarde, do betão armado, no segundo quartel do século $X X$, vai coincidir com o endurecimento do regime colonial para com os povos não-europeus, especialmente os africanos. Ao mesmo tempo começam a ganhar força os movimentos nacionalistas que provinham essencialmente das elites assimiladas, descontentes com o entrave à sua ascensão social na hierarquia colonial (Moreira,1997). No contexto suburbano as habitações de madeira e zinco passariam, assim, a assumir uma conotação de resistência perante o poder colonial que o cimento, vulgo colonizador, exercia sobre o caniço, vulgo colonizado. Ainda hoje são visíveis na Mafalala as antigas casas de madeira e zinco de alguns protagonistas da libertação moçambicana, como Samora Machel, Joaquim Chissano, Noémia de Sousa, José Craveirinha, entre outros, sendo muitas delas preservadas como memória dos tempos de resistência ao colonialismo. 


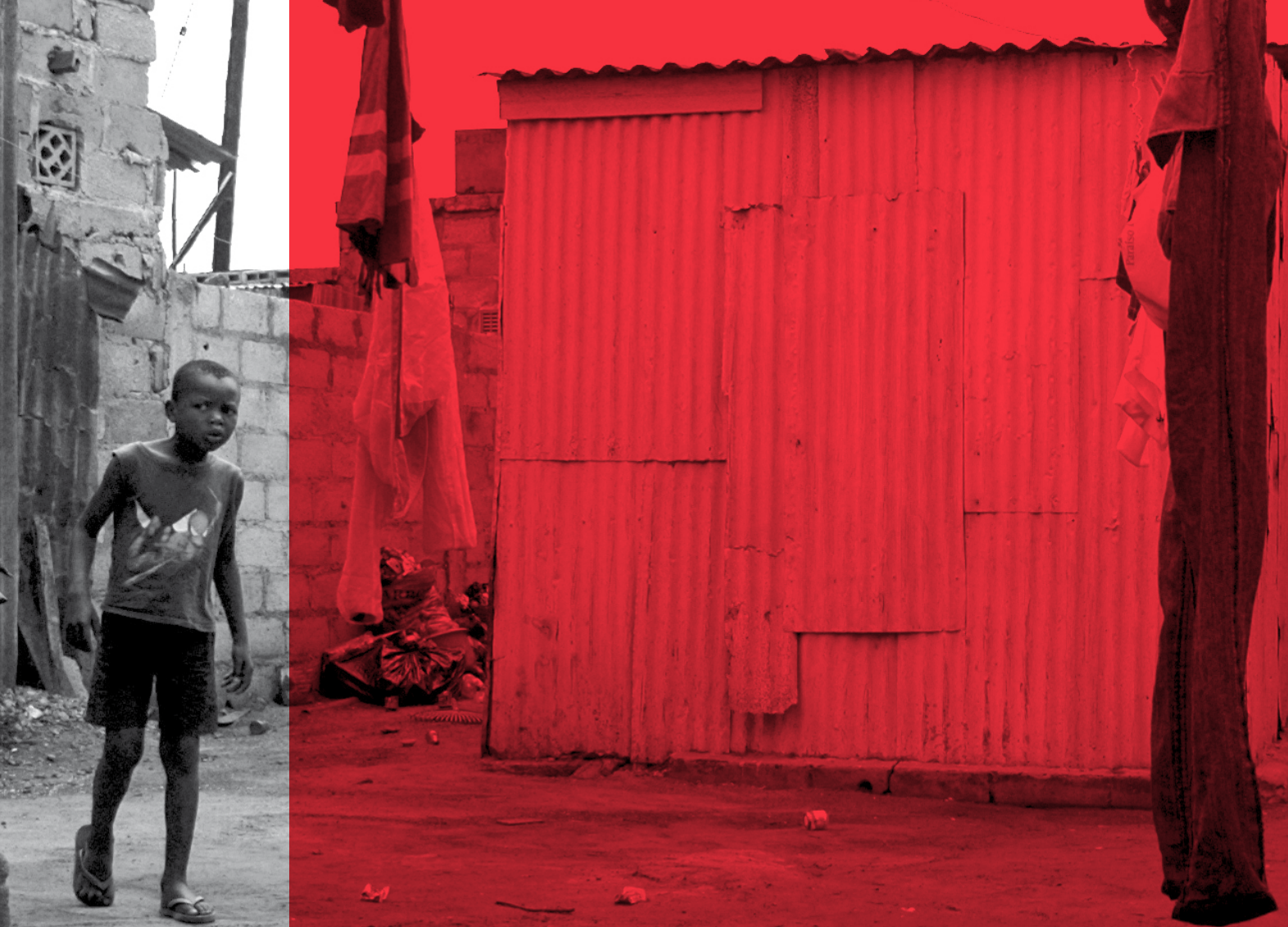

Casa onde viveu Joaquim Chissano, 2013.

\section{A fechar}

O espaço urbano da Mafalala é demasiado rico para se poder resumir em tão poucas palavras. Para conhecê-lo é preciso experienciá-lo, embrenhar-se nas suas ruas e ruelas, disfrutar da amabilidade dos seus habitantes, travar conhecimento com alguns. Escutar as histórias, não só dos mais velhos e sábios, profundos conhecedores da história do bairro de outros tempos, como as dos mais jovens e promissores, com todos os sonhos, anseios e novas perspetivas para o presente e futuro da Mafalala.

Para que a herança do bairro não se perca no tempo, é fundamental dar voz às diferentes gerações que nele coabitam. Passadas quatro décadas de independência em Moçambique, as memórias dos que, na Mafalala, lutaram pela liberdade, têm-se desvanecido, lentamente. É imperativo preservar estas memórias, reavivá-las no seio do bairro e dos seus habitantes, e reconhecer a sua importância na história do país. Elas são parte do espaço urbano da Mafalala. 


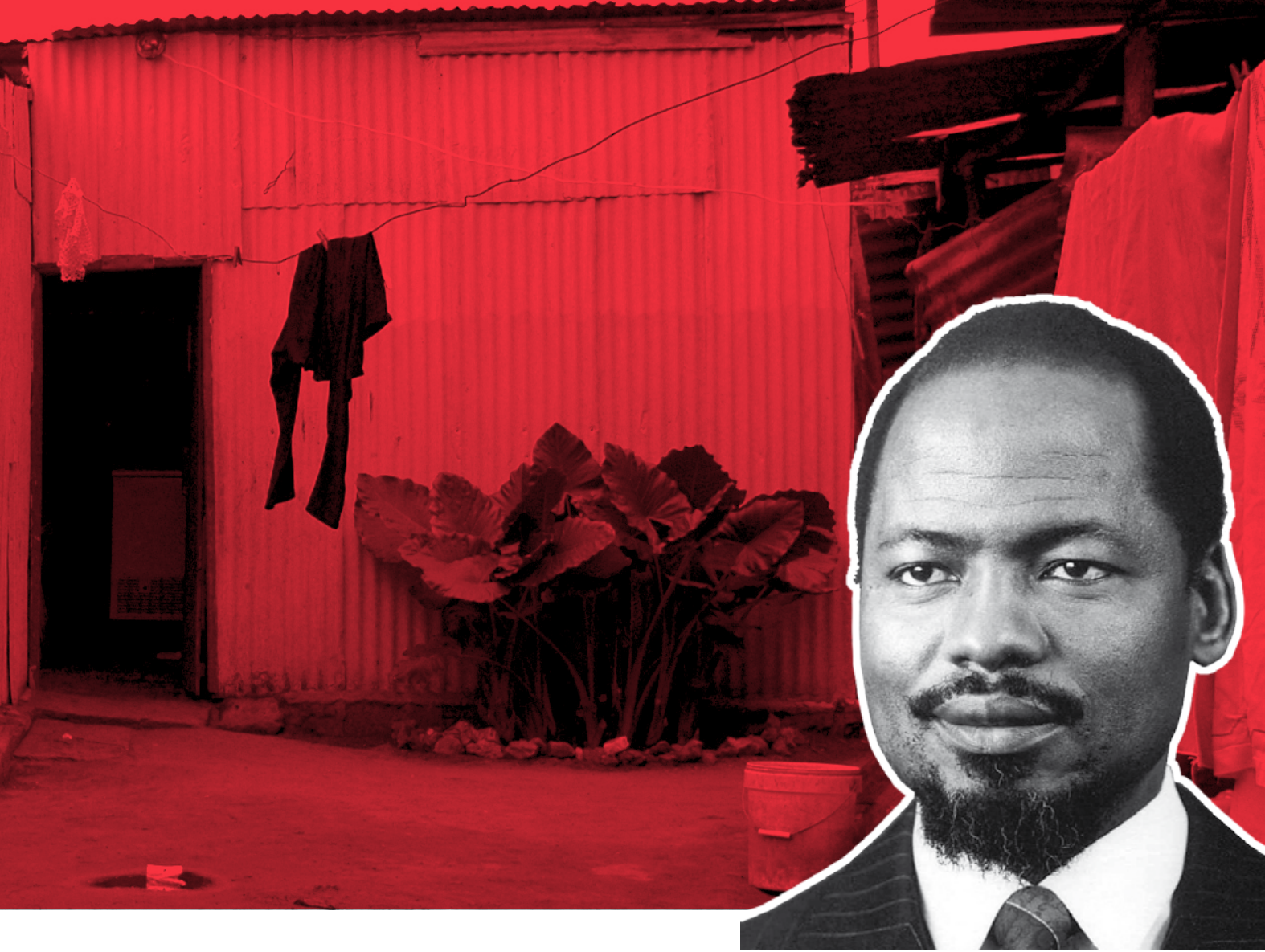


1 Designação colonial dos subúrbios de algumas cidades moçambicanas, como Lourenço Marques e Beira, onde predominavam construções com este tipo de material vegetal. Na capital era recolhido, na sua maioria, das zonas alagadiças do Infulene.

2 Povo predominante a sul do rio Save, com várias ramificações, entre as quais, os Chopes, de Zavala, ou os Tongas, de Inhambane.

3 Os termos mais comuns são: township (África do Sul), umjondolo (Zulu, Durban), mussekes (Angola), caniço (Moçambique), mabanda (Kiswahili, Tanzânia), bairro da lata (Portugal), favelas (Brasil), villa miséria (Argentina), slum (Inglaterra), bidonvilles (França).

4 Publicado no periódico Lourenço Marques Guardian, 14 de junho de 1909. Agradeço a António Sopa esta referência.

5 Esta proibição iria manter-se até ao início da década de 1960, sendo uma das causas da precariedade habitacional nos subúrbios. Native locations ver Frescura (2001: 68)

6 No urbanismo colonial britânico, as locations eram zonas urbanas específicas onde as autoridades coloniais confinavam os grupos somáticos não-europeus. As mais comuns eram as native locations, equivalente aos bairros indígenas do colonialismo português, as coloured locations, para os mestiços, as coolie locations, para asiáticos (indianos e chineses) (Frescura, 2001: 68).

7 Conhecida por Avenida Caldas Xavier até à independência, hoje Avenida Marien N'Gouabi.

8 Uma das formas como se designava os limites da xilunguíne no início do seculo XX (Nyeleti, 1912: 1).

9 "O que será da raça negra, a legítima proprietária dos territórios cobiçados, anexados e em breve ocupados pelos brancos".

10 Decreto de 23 de março de 1895.

11 Aprovado em 9 de julho de 1909, adaptado para Moçambique a partir do Regime para a concessão de terrenos no Ultramar, decreto de 9 de maio de 1901.

12 Forma como se designava a circunvalação na metrópole desde meados do seculo XIX. A mesma grafia foi usada para designar a circunvalação na Planta da Cidade de Lourenço Marques e Subúrbios, impressa em 1912, onde se registou, a mando da Câmara Municipal, os dados topográficos recolhidos pela Agrimensura entre 1907 e 1908.

13 No caso de Lisboa, a primeira linha de circunvalação foi construída de 1845 a 1850 para facilitar a fiscalização e cobrança de impostos sobre mercadorias entradas em Lisboa vindas por terra. "Projeto de Ampliação da Cidade", elaborado em 1887 pelo Major António José de Araújo. Seria aprovado oficialmente cinco anos mais tarde, devido às negociações com os proprietários dos terrenos onde a malha ortogonal foi projetada e implantada (Liesegang, 1987: 40).

15 Estas zonas eram conhecidas no urbanismo francês por cordon sanitaire. De forma semelhante, a versão colonial britânica, buffer zone, servia para separar as native locations dos outros grupos, principalmente dos europeus. 
Segundo as Posturas Municipais em vigor na Cidade de Maputo, compiladas pelo MICOA em 1998, "a divisão dos terrenos da cidade [é em] talhões numerados e estes em parcelas, estendendo-se por talhão o terreno circundado por ruas e avenidas, e por parcelas as partes em que estes talhões se dividem".

17 Segundo Frescura (2001: 68), o termo provém do malaio kampong, que significa recinto, estaleiro. Eram espaços habitacionais confinados e insalubres onde as empresas de mineração sul-africanas alojavam os mineiros africanos (Moroney, 1978). O modelo foi adaptado para Lourenço Marques pelos engajadores de mão de obra, como a WNLA, que aí mantinham os seus trabalhadores, alguns em trânsito para as minas do Transvaal e outros para o chibalo da capital (Penvenne, 1993: 158).

18 Paola Berenstein Jacques (2001) ilustra este fenómeno de uma forma semelhante para o caso das favelas do Rio de Janeiro, remetendo para um sistema de rizoma, que se vai enraizando, penetrando e moldando no espaço suburbano.

19 Também conhecida em Maputo por xicalamidades, é um comércio informal de vestuário usado doado por países estrangeiros para ajudar as vítimas de calamidades naturais. Em particular as ilhas de Moçambique, Comores, Zanzibar e Madagascar (Alpers, 2001).

21 Termo colonial pejorativo para designar os povos de religião muçulmana em Moçambique.

22 Esta resistência é evidente em vários artigos publicados no periódico $O$ Africano no primeiro quartel do século XX, onde as críticas à cultura swahíli (designada na altura por macua) eram recorrentes. O ritual religioso mais comum era o Rifa'iyya Dhikr, celebrado por alguns swahílis moçambicanos por altura do Maulide e que tinha ligações a congéneres de Zanzibar e Comores, sendo uma das influências da dança do tufo (Bonate, 2007: 66-72). Segundo um dos artigos d'O Africano (190905-22), este ritual Dikhiri (Dhikr) fazia um "barulho infernal [...] que, numa casa da Munhuana, dezenas de macuas cantavam 'ha, ha, ha, ha' durante horas". É possível que a corruptela 'ha, ha, ha, ha' remeta para parte do refrão hipnótico do Dhikr que refere repetidamente "Allah, Allah, ...", sendo provável o seu contributo fonético para o nome da Mafalala.

24 Instalou-se na llha de Moçambique, em 1897, por um Xêhê das Comores (Carvalho, 1988: 61). Na Mafalala, das três confrarias desta ordem, duas estavam ligadas à Ilha de Moçambique, a Chadulia e a Itifaque (ou Camaria, criada em na llha em 1936), e a outra às Comores, a Baraza (Bonate, 2007: 206).

25 Ou Cadiria, instalou-se na Ilha de Moçambique, em 1904, por um Xêhê de Zanzibar (Carvalho, 1988: 63).

26 Foi a partir de muitas cantinas dos subúrbios de Lourenço Marques, em especial das dos europeus, que se geraram alguns focos de violência dos conturbados meses de setembro e outubro de 1974.

27 Algo semelhante aconteceu noutros assentamentos espontâneos em ambientes urbanos como, por exemplo, nas favelas brasileiras (Jacques, 2001).

28 Termo ronga para designar povoação, normalmente pertencente a um clã ou família alargada que 
se entreajuda, muitas vezes na edificação das habitações (Waterhouse, 2001: 129). É interessante verificar que no ambiente das favelas brasileiras existe a expressão mutirão com um significado semelhante à entreajuda comunitária (Piccolo, 2009: 94; Houaiss, 2015: 2718).

29 Termo ronga para designar a cobertura cónica das suas habitações. Estes e os restantes termos desta língua foram retirados dos Diccionarios shironga-portuguez e portuguez-shironga, precedidos de uns breves elementos de grammatica do dialeto shironga, falado pelos indígenas de Lourenço Marques, de Ernesto Torre do Valle, editado pela Imprensa Nacional, em 1906.

30 De salientar o pormenor no desenho da casa de planta retangular que se encontra à beira da encosta, entre a feitoria holandesa e a povoação Mpfumu, o que denota já alguma contaminação desse modelo.

31 Excerto de um artigo no periódico Lourenço Marques Guardian, 23 de junho de 1910, publicado por Lima (1968: 64-65).

32 Excerto de um artigo no periódico O Africano, 15 de maio de 1915, sobre o pagamento do imposto predial nos subúrbios.

33 Apelidados de mampara magaíza ou mambarha gayiza e, mais tarde, de madjonidjoni (Mungoi, 2010: 211-215).

\section{Bibliografia}

Alpers, Edward A. (2001), "A Complex Relationship: Mozambique and the Comoro Islands in the 19th and 20th Centuries", Cahiers D'études Africaines, 41 (161): 73-96.

Bonate, Liazzat J. K. (2007), Traditions and Transitions: Islam and Chiefship in Northern Mozambique, Ca. 1850-1974 (PhD). Cape Town: University of Cape Town.

Cabaço, José Luis, (2007), Moçambique: identidades, colonialismo e libertação (Dissertação de Doutoramento). São Paulo: Universidade de São Paulo. Câmara Municipal de Lourenço Marques (org.) (1953), Anais da Câmara Municipal de Lourenço Marques: 1951. Lourenço Marques: Imprensa Nacional de Moçambique.

Carrilho, Júlio (2005), Ibo, a Casa e o Tempo. Maputo: FAPF.

Carrilho, Júlio; Lage, Luís; Bruschi, Sandro (2005), Era uma vez uma palhota: história da casa moçambicana. Maputo: FAPF.

Carvalho, Álvaro Pinto (1988), "Notas para a história das confrarias islâmicas na llha de Moçambique", Boletim do Arquivo Histórico de Moçambique, n. ${ }^{\circ} 4$ (especial): 59-66. 
Castilho, Augusto de (1880), O districto de Lourenço Marques, no presente e no futuro. Lisboa: Sociedade de Geographia de Lisboa. Dores, Hugo Gonçalves (2014), Uma missão para o império: política missionária e o "novo imperalismo" (1885-1926) (Dissertação de Doutoramento). Lisboa: UI/ ISCTE-IUL/ UCP/ UE.

Frescura, Franco (2000), "Deconstructing the Apartheid City", 26, HSRC, Pretoria.

Frescura, Franco (2001), "The Spatial Geography of Urban Apartheid", in Abebe Zegeye; Robert Kriger (orgs.), Culture in the New South Africa (vol.2). Roggebaai: Kwela Books: 65-90.

Gros, Marielle Christine (1982), O alojamento social sob o fascismo. Porto: Afrontamento.

Harries, Patrick (1989), "Exclusion, Classification and Internal Colonialism: The Emergence of Ethnicity Among the Tsonga-Speakers of South Africa", in Leroy Vail, The Creation of Tribalism in Southern Africa. Los Angeles: University of California Press: 77-117.

Harries, Patrick (1994), Work, Culture, and Identity: Migrant Laborers in Mozambique and South Africa, C.1860-1910. Johannesburg: Witwatersrand Univ. Press.

Houaiss, António (2015), Grande Dicionário Houaiss da Língua Portuguesa (Vol. 5). Lisboa: Círculo de Leitores.

Jacques, Paola Berenstein (2001), "Estética das favelas (arquitextos 013.08)", Vitruvius. Consultado a 15-05-2016, em http://www.vitruvius. com.br/revistas/read/arquitextos/02.013/883.

Jerónimo, Miguel Bandeira; Domingos, Nuno (2015), “Do indígena ao imigrante", in Nuno Domingos; Bruno Monteiro (orgs.), Este país não existe. Porto: Deriva: 135-142.

Junod, Henri Alexandre (1898), Les Ba-ronga: étude ethnographique sur les indigénes de la baie de Delagoa. Moeurs. Neuchâtel: Attinger. Junod, Henri Alexandre (1912), The Life of a South African Tribe. The Psychic Life (Vol. 2). Neuchâtel: Attinger.

Laranjeira, Rui (2014), A Marrabenta: Sua Evolução e Estilização, 19502002. Maputo: Minerva Central.

Lemos, Manuel Jorge Correia de (1988), "Reviver a Ilha, na Mafalala", Boletim do Arquivo Histórico de Moçambique, n. 4 (especial): 49-58. Lima, Alfredo Pereira de (1968), Casas que fizeram Lourenço Marques. Lisboa: Centro de Estudos Históricos Ultramarinos. 
Mendes, Maria Clara Teles (1985), Maputo antes da independência: geografia de uma cidade colonial. Lisboa: Instituto de Investigação Cientifica Tropical.

Mitchell, Hilary Flegg (1975), Aspects of Urbanisation and Age Structure in Lourenço Marques (Maputo). Lusaka: NECZAM (University of Zambia, Institute for African Studies).

Moreira, José (1997), Os Assimilados, João Albasini e as Eleições, 1900-1922. Maputo: Arquivo Histórico de Moçambique.

Moroney, Sean (1978), "The development of the compound as a mechanism of worker control 1900-1912". Consultado a 15-05-2016, em http://wiredspace.wits.ac.za/handle/10539/8009.

Mungoi, Dulce Maria Domingos Chale João (2010), Identidades viajeiras: família e transnacionalismo no contexto da experiência migratória de moçambicanos para as minas da terra do Rand, África do Sul (Dissertação de Doutoramento). Porto Alegre: Universidade Federal do Rio Grande do Sul.

Njoh, Ambe. 2007. Planning Power: Town Planning and Social Control in Colonial Africa. London: Routledge.

Noronha, Eduardo de (1895), O districto de Lourenço Marques e a África do Sul. Lisboa: Imprensa Nacional.

Nyeleti, Franco Martins (1912), "Matriz Predial", O Africano, Abril 5. Penvenne, Jeanne Marie (1993), Trabalhadores de Lourenço Marques: 1870-1974: antologia de artigos. Maputo: Arquivo Histórico de Moçambique.

Pereira, Guilherme da Silva (1971), "Bairro da COOP. Peregrinação semanal. Caniço, agua a mais, agua a menos", Revista Tempo, Junho 20. Piccolo, Fernanda Delvalhas (2009) "Memórias, histórias e representações sociais do bairro de Vila Isabel e de uma de suas favelas (RJ, Brasil)" , Etnográfica. Revista do Centro em Rede de Investigação em Antropologia, 13 (1): 77-102.

Rita-Ferreira, António (1968), "Os africanos de Lourenço Marques", Memórias do Instituto de Investigação Científica de Moçambique, (1967/68), 9: 95-491.

Silva, Teresa Cruz e (2000), "Identidades étnicas como fenómenos agregadores num espaço social urbano: os casos de Mafalala e Chinhambanine", in Carlos Serra (org.) Racismo, etnicidade e poder: um estudo em cinco cidades de Moçambique. Maputo: Livraria 
Universitária da Universidade Eduardo Mondlane: 195-208.

Sopa, António (2014), A alegria é uma coisa rara: subsídios para a história da música popular urbana em Lourenço Marques (19201975). Maputo: Marimbique, Conteúdos e Publicações.

Voth, Hans-Joachim (2004), "Living standards and the urban environment", in Roderick Floud et al. (orgs.), The Cambridge Economic History of Modern Britain. Cambridge: Cambridge University Press: 268-94.

Warr, Anne (2001), "Making corrugations: a cultural journey", From Point to Pathway: the Heritage of Routes \& Journeys. Consultado a 1505-2016, em http://www.aicomos.com/wp-content/uploads/Makingcorrugations-a-cultural-journey.pdf.

Waterhouse, Rachel (2001), Gender Dimensions of Land Policy in Contemporary Mozambique: A Case Study of Ndixe Village, Marracuene District, Southern Mozambique (PhD). Cape Town: University of Cape Town. 
